\title{
THE EFFECTS OF THE 2008/9 ECONOMIC RECESSION ON NGO SUSTAINABILITY AND FUNCTIONING IN THE SOUTH AFRICAN SOCIAL SERVICES, HEALTH AND EDUCATION SECTORS
}

\section{Eyesus Gebreselassie-Hagos; André de V Smit}

\section{INTRODUCTION}

The economic crisis of 2008/2009 first emerged in the developed economies in 2008 and spilled over into developing countries and economies in transition through international financial and trade channels. This is the greatest financial crisis the world has faced since the Great Depression (Hanfstaengl, 2010; Sandra, 2008). At the height of the recession many feared that it would change into a depression. Banks were "unwilling to lend, credit spreads had widened sharply, stock markets had plunged and economies everywhere were stumbling" (Bustillo \& Velloso, 2009:7). Some of the immediate effects of the economic recession on society included higher food prices and other living costs. Furthermore, corporations experienced reductions in their profit margins. It could reasonably be assumed that the NGO sector would suffer significantly as corporate donors and philanthropists typically contribute less during economic downturns.

Although previous studies have examined the impact of the economic crisis on NGOs, most of the studies have focused on multinational NGOs. None have focused specifically on the South African context. NGOs are the cornerstone of South African society as government alone cannot address all societal needs. Their contributions to service delivery are very considerable. As such, a better understanding of the impact that the economic crisis has had and/or will have on this sector is thus imperative.

This study will report briefly on the structure and nature of the South African NGO sector and the service delivery partnership that it has with government and the outcomes of similar studies conducted elsewhere will be presented. The research intent, method and electronic survey technique used will be briefly described. The impact of the recession on the three named sectors will be discussed in concert with related findings of research done elsewhere. Limited recommendations based on these findings are also proffered.

\section{NGO SECTOR IN SOUTH AFRICA}

While the history of the NGO sector in South Africa dates back to the early part of the twentieth century, a large and vibrant NGO sector in South Africa emerged after 1980 (Swilling \& Russell, 2002). In addition to the large number of "traditional" NGOs (which were perceived to be part of the political establishment of the time), a significant number of "progressive" NGOs were established in an effort to bring about a democratic dispensation in South Africa. The 'traditional' NGOs entered into a partnership with the state - they provided services on behalf of government in return for financial assistance in the form of subsidies. State control of this sector during this period was affected by various statutes. Of note were the Fundraising Act, 1978 (Act 107 of 1978) and the Disclosure of Foreign Funding Act, 1989 (Act 26 of 1989). The former Act required 
registration and full reporting on income and expenditure. The latter Act, though not fully implemented, was aimed specifically at the "progressive" NGOs, who refused local (particularly state) funding and sought international funding instead, and it made reporting on all sources of foreign funding and other confidential information mandatory. Both Acts have since been repealed.

Despite statutory restrictions, much funding came into the country to support the services of various NGOs, especially those supporting disempowered communities and those opposing the policies of the apartheid government. This foreign funding was behind a significant expansion of the South African NGO sector. However, in the immediate post-apartheid period, South African NGOs faced challenges due to a loss of this foreign funding as donors started diverting their funds elsewhere in the belief that South African NGOs no longer needed their support, given that South Africa now had a democratically elected government. Furthermore, the anticipated incorporation of the "progressive" NGOs into the "traditional" NGO fold (and hence receiving state support) did not fully materialise. Despite the significant political changes, South African NGOs have increasingly faced difficulty in sustaining service output as a result of inadequate funding, lack of skilled workers and insufficient management capacity (Kilbey, 2010; Smit, 2005; Swilling \& Russell, 2002).

\section{INTERNATIONAL NGOS' EXPERIENCE OF THE ECONOMIC RECESSION}

NGOs experienced the economic recession in diverse ways. The literature highlighted an interesting juxtaposition, namely that while the economic recession threatened the functioning of NGOs, it also fostered creativity and innovation.

Various studies revealed that NGOs reported decreases in all major categories of funding during the economic recession. These sources included corporate sponsorships, corporate grants, major gifts, foundation grants, small individual gifts and special events (Alliance for Nonprofit Excellence, 2009; Hanfstaengl, 2010; Social Planning Network of Ontario (SPNO), 2009). Furthermore, NGOs experienced either reduced or no funding from local, state and federal funding agencies and some NGOs also experienced delays in payment of grants and contract fees (Alliance for Nonprofit Excellence, 2009). Revenue declines were also due to a decline in endowment funding and decreased cash flows as a result of restricted credits and government delays (Alliance for Nonprofit Excellence, 2009; Salamon, Geller \& Spence, 2009; Vancouver Foundation, 2009). Apart from reduced income, budget shortfalls were also occasioned by greater expenditure necessitated by increased service demands. However, at the same time some NGOs reported increases in in-kind donations, special events and small individual gifts (Alliance for Nonprofit Excellence, 2009). However, the degree of increased support was smaller than the degree of decreased support.

Studies indicated that the economic recession threatened cash reserves, which are a safeguard for organisations, especially during times of economic turmoil (Alliance for Nonprofit Excellence, 2009; Foster, Perreault \& Sable, 2009:7). The Alliance for Nonprofit Excellence study (2009:2), indicated that of the organisations that had cash 
reserves, $37 \%$ had funding for 1-6 months and 14\% for 6-12 months. Further, 30\% of those with reserves said they had begun spending them to cover budget shortfalls due to the economic recession, while $49 \%$ indicated that they would end that fiscal year with a budget deficit (Nonprofit Excellence study, 2009:2). Foster et al. (2009:7) also indicated that the economic recession forced NGOs to tap into their financial reserves.

The economic recession also affected the nature and scope of services needed by clients and organisations' ability to deliver these. Most studies indicated that the economic recession led to an increased service demand (Alliance for Nonprofit Excellence, 2009; Hanfstaengl, 2010; Social Planning Network of Ontario, 2009; Social Planning Council of Cambridge and North Dumfries, 2009: Calgary Chamber of Voluntary Organisations (CCVO), 2009). Forty-three per cent of respondents in the Alliance for Nonprofit Excellence study (2009:4) revealed that they had experienced qualitative changes in service demand, including increases in more 'severe' 'urgent' and 'dramatic' needs related to health conditions, co-occurring disorders, dangerous living conditions and extreme hunger. Furthermore, a wider array of services was requested such as substance abuse treatment in addition to mental health care or financial assistance as well as housing.

Many respondents noted that their client profiles had greatly expanded to include people who did not previously require their services. Organisations that had client threshold requirements such as maximum income levels stated that many more applicants were meeting these requirements than before. The SPNO study (2009:2) reported similar findings, with $60 \%$ of the respondents reporting that demand for services such as employment creation, job training programmes, and bankruptcy and credit counselling had mostly increased. This study also found that mental health counselling, suicide and crisis intervention programmes were in greater demand (The SPNO study, 2009:2). Furthermore, $97 \%$ of the respondents indicated an increased number of people requesting their services since 2008 , while $49 \%$ of respondent organisations had to focus on crisis intervention and thus had less time for preventative programmes (The SPNO study, 2009:2). Seventy-two per cent reported that they found increased complexity in the needs of the people they served (The SPNO study, 2009:3).

The findings of the Social Planning Council of Cambridge and North Dumfries (2009) survey showed the impact of the increased service demand on organisations. Some of these impacts included increased caseloads, more hours worked without additional staff, increased stress on staff and organisations, the inability to provide clients with the holistic support they needed, increased human resources costs, volunteer burnout, increased waiting times, increased reliance on fees for service work and increased human resources investment in securing additional funding sources (Social Planning Council of Cambridge and North Dumfries, 2009:3). There was no indication that additional funding to meet this increased demand was forthcoming.

In a multi-continent survey of non-profit organisations' (NPOs) use of information technology to better market services and to improve sustainability, Kanithi (2010:118) reported that $93 \%$ of respondents reported positive experiences. Interestingly, while $84 \%$ 
of NPOs in developing countries used email requests as an online fundraising strategy, only $40 \%$ of NPOs from developed countries did so (Kanithi, 2010:147). However, online donation strategies were more commonly used by NPOs from developed countries (62\%) than their counter parts in developing countries (44\%) (Kanithi, 2010:147). Furthermore, 23\% of NPOs from developed countries employed selling of goods online as a fundraising strategy, whereas only six per cent of NPOs from developing countries employed this strategy (Kanithi, 2010:147).

\section{SOUTH AFRICAN NGOS' EXPERIENCES OF THE ECONOMIC RECESSION}

NGOs in South Africa provide various basic services, mainly in the social, educational and health sectors (Kalis, 2000). The recent economic crisis threatened the sustainability of the South African NGO sector at a time when their services were already in high demand as international and local, particularly corporate, sources of funding decreased. At the same time, the demand for NGO services increased as many people were out of work and turned to NGOs for assistance, forcing NGOs to extend their services to meet this increased need - this despite their funding constraints. Like their international counterparts, South African NGOs were also affected by the economic recession.

Rapoo (2010:1) reported a significant decline in the funding that South African NGOs received from international donors because of the economic recession, in some cases reportedly by as much as 30 per cent. Further, NGOs dependent on international donors were more affected by the economic recession compared to those who were not, as international sources of funding reduced or withdrew funding due to low profit margins and/or losses (Rapoo, 2010:1). This was also confirmed by Philip (2009), who reported that HIV/AIDS, animal welfare and educational causes experienced budgetary crises as foreign, corporate and private donors all donated less or cancelled debit orders because of the economic recession. According to McLead, co-owner of fundraising consultancy Downes Murray International, new donors were taking longer to agree to support organisations as evidenced by a drop of $20 \%$ in individual donor responses to her organisation's direct mail requests (Salgado, 2010:1). Similarly, others reported a drop in corporate giving and noted that lower profits made it tougher to raise funds from the corporate sector in 2010 (Salgado, 2010).

According to Philip (2009:1), charity organisations that represented $30 \%$ of the social service organisations in South Africa were expected to have R3 billion less to spend on crucial services as a direct consequence of the recession. Child Welfare South Africa reported that they experienced a financial crisis while the Nelson Mandela Trust reported a cut in services as a result of fewer individual donations, resulting in financial distress (Philip, 2009). Some NGOs in the Western Cape closed their doors to communities because of the economic recession, principally due to less international donor aid (Peter, 2008).

According to Naidoo and Nkuna (2009), financial difficulty and increased service demand occasioned by the economic recession resulted in the closure of a number of South African NGOs - such closures significantly affected those needing the services. 
According to Ajam (2009) and Thaw (2009), donors declared that there was less money available for NGOs because of the economic recession. Salgado (2010) also confirmed that corporate funding had decreased as a result of the recession.

Despite this drop in funding, Salgado (2010) stated that according to the South African Institute for Advancement, wealthy South Africans were still giving despite the recession, though there was a slight drop in funding from the middle and poor classes. Franzen, a trustee of the Red Cross Children's Hospital Trust, stated that it was much tougher to raise funds from corporates, though support from existing donors that had strong links with their chosen charities was still forthcoming (Salgado, 2010). She further highlighted that even though the economic recession was tough for many organisations, there was evidence that there was money floating around (Salgado, 2010).

\section{MEASURES ADOPTED TO CURB THE EFFECT OF THE ECONOMIC RECESSION}

Understandably, many NGOs rose to the occasion in an attempt to deal with the economic recession, particularly in relation to the increased service demand and reduced funding.

The most common measures adopted were an intensification of focus on the dwindling sources of income. Among other things, funding strategies were revised, new types of funding were pursued, travel and training were reduced, programmes and services were cut and service partnerships with other organisations were formed (Alliance for Nonprofit Excellence, 2009; Calgary Chamber of Voluntary Organisations, 2009; Hansfstaengl, 2010; Salamon et al., 2009). Staff-related responses included layoffs, reduction of fringe benefits, modifying staff costs by cutting positions, reduction of staff hours, replacing full-time staff with part-time staff and interns, freezing salary increases and vacant posts, and salary cuts (Alliance for Nonprofit Excellence, 2009; Calgary Chamber of Voluntary Organisations, 2009; Hansfstaengl, 2010; Salamon et al., 2009). Other measures adopted included outsourcing, cancelling special events and renegotiating contracts (Hanfstaengl, 2010). Fifty-two per cent of the respondents in the Alliance for Nonprofit Excellence study (2009:3) indicated that their organisations had adopted scenario planning to consider the impact that changes to their income, operating environment, and/or service needs would have on their service outputs and to develop appropriate strategies to deal with such changes.

The improved use of information technology, reductions in administration, staffing and programme costs, adoption of appropriate strategies, and funding from wealthy individuals enabled many organisations to survive the negative consequences of the recession (Hanfstaengl, 2010:32; Salamon et al., 2009:2). Other measures adopted included traditional strategies such as increased diligence in managing funds, diversification and the improvement of financial management systems (Hanfstaengl, 2010:32; Salamon et al., 2009:2). Furthermore, in the Hanfstaengl study, slightly more than half of the respondents from Latin American countries reported that they had to narrow their scope of work, while $72 \%$ of Sub-Saharan African countries narrowed their scope of work, $64 \%$ reduced their number of staff, $82 \%$ started additional fundraising 
campaigns and $81 \%$ reported that they were seeking networking with other locally based community service organisations (CSOs) (Hanfstaengl, 2010:32). In Asia, while 60\% respondents were able to improve the efficiency of their work, $58 \%$ had to narrow their scope of work, $59 \%$ reduced their staffing, $79 \%$ embarked on an additional fundraising campaign and 63\% developed additional skills using internet tools (Hanfstaengl, 2010:33).

The respondents from the SPNO study (2009:26) adopted a number of strategies, namely supporting more people with the same staffing level $(46 \%)$, increasing fundraising efforts (45\%), applying for funding from another funding source (37\%), increased use of volunteers $(34 \%)$, using agency reserves to cover programme hours $(33 \%)$, reducing professional development resources (33\%), engaging in new partnerships (31\%), increased unpaid management overtime (29\%) and reducing agency administrative support or systems (26\%).

Furthermore, according to the SPNO study (2009:23), other strategies that organisations adopted included supporting more people with the same staff complement (69\%) and increasing volunteer resources $(46 \%)$. The rest portrayed an expansion of programme staff time and service hours (28\%), fundraising more private dollars to expand programmes (27\%) and the reallocation of agency administrative dollars (24\%) to expand programmes (SPNO study, 2009:24).

On the other hand, the Social Planning Council of Cambridge and North Dumfries study (2009) revealed that organisations were unable to respond effectively to the increased demand for their services. A few indicated that they were doing exactly what they used to do, while others indicated that they reallocated administrative resources to extend programmes, redirected funds between programmes and increased volunteer hours.

"Tough times lead to tough choices, but there is a tangible opportunity for non-profits to emerge stronger and smarter" (Social Planning Network of Ontario, 2009:9). Clearly the economic recession afforded NGOs ample opportunity to be innovative and to creatively address the shortfalls that they experienced. Some of the strategies adopted included reaching out to new sources of funding, improved recruitment and retention strategies by offering more competitive salaries, increased collaboration and partnership in sharing space and services to reduce costs, greater use of volunteers, more efficient use of resources and increased financial accountability and transparency (Calgary Chamber of Voluntary Organisations, 2009; Salgado, 2010; Social Planning Network of Ontario, 2009).

Undoubtedly, many of the measures adopted strengthened organisations in such a way that they are now better placed to weather such storms.

\section{STUDY INTENT AND METHOD}

Given the findings of research conducted elsewhere, the authors set out to better understand the impact that the 2008/2009 economic recession had on South African NGO sustainability and functioning. As such, the study sought to determine the changes in revenue streams and the impact of this on operations and staffing. It further sought to 
assess what, if any, strategies were adopted to mitigate any negative impact that the recession may have had on organisations.

This quantitative study sourced its respondents from a population that constituted all NGOs operating in the social service, health and education sectors that were listed in the South Africa Prodder Directory as at November 2010 (South African NGO Network (SANGONet), 2011). Prodder is a comprehensive directory, established as a development publication and reference tool in Southern Africa. The population consisted of 813 organisations listed in the three sectors indicated. A probability sampling technique was adopted (population served as sample) and of the 813 listed organisations (364, 227 and 222 NGOs were working in the social service, health and education sectors, respectively) only 637 were deemed valid as some organisations failed to receive the email as their email accounts were inactive, or the organisations no longer existed, or organisations did not update their current email address on Prodder, or they had merged with other organisations without updating the information on Prodder. Of the 637 organisations that constituted the sample, 63 responded - a response rate of 10 per cent. This was in accordance with current electronic survey response rates. A significant limitation of online surveys is the low response rate. Ethical considerations dictate that participation is voluntary, that withdrawal of participation can take place at any time and also result in selective response to questions (Fielding, Lee \& Blank, 2008). Furthermore, response rates in web-based surveys are generally low and vary from less than one per cent for enterprise surveys with email invitations to almost one hundred per cent in specific membership surveys (Fielding et al., 2008).

The data collection instrument for this research was a self-administered survey questionnaire. While not appropriate for mining data on more complex issues and opinions, it is the most suitable instrument to access a large number of respondents, quickly, effortlessly and efficiently. The questionnaire was hosted by SurveyGizmo, an internationally used electronic/online survey tool. Respondents were sent a URL via email which, when activated, presented them with the electronic questionnaire. The data from the electronic questionnaire was exported automatically into Microsoft Excel spread sheets and analysed.

Another limitation was that the study concentrated only on organisations that operated in the social services, health, education sectors in South Africa. This research would have been more valuable if it had included perceptions of funders, service beneficiaries and personnel within the organisations to acquire more realistic and comprehensive data.

\section{LOCATION OF RESPONDENT ORGANISATIONS AND SECTORS OF OPERATION}

South Africa is divided into nine provinces. Twenty-three $(38 \%)$ of the respondent organisations were located in Gauteng, $17(28 \%)$ in the Western Cape, 11 (18\%) in KwaZulu-Natal, 4 (6\%) in North West, 3 (5\%) in the Eastern Cape, 2 (3\%) in Limpopo and $1(2 \%)$ in Mpumalanga. There were no responses from Northern Cape and the Free State. 
108

Twenty-four $(39 \%)$ of the respondent organisations identified themselves as working in the social services sector, followed by $14(23 \%)$ that operated in the education sector and $9(15 \%)$ that reported operating in the health sector. Eight organisations $(13 \%)$ worked in the social service and health sectors, $3(5 \%)$ worked in the social service and education sectors, while $3(5 \%)$ operated in all three sectors. The services rendered by 38 organisations operating in the social service sector are reflected in Graph 1. Services were mostly focused on child, youth and family welfare services.

\section{SOCIAL SERVICE SECTOR SERVICES}

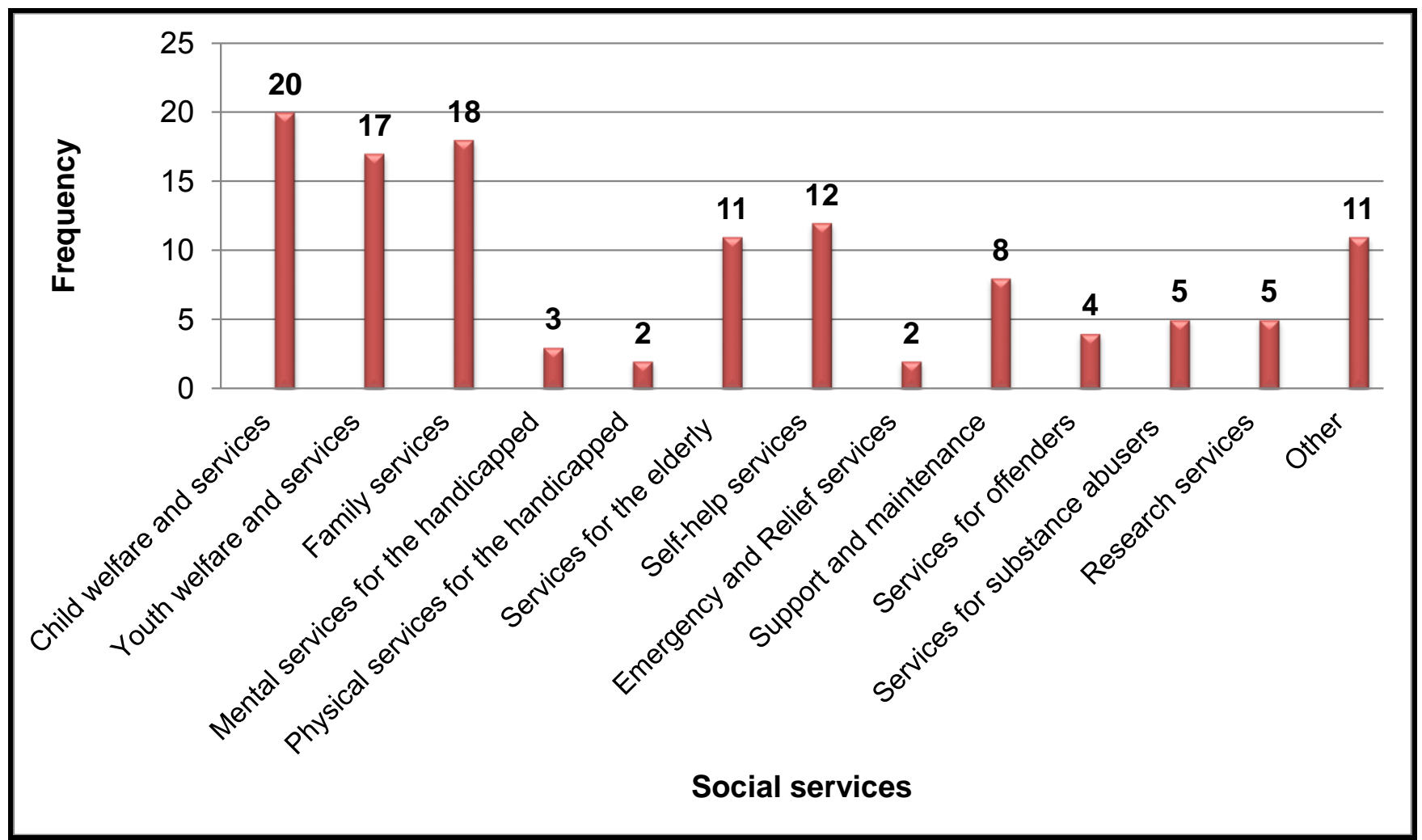

Twenty organisations reported that they worked in the education sector and the services that they rendered are reflected in Graph 2. Significantly, $11(55 \%)$ organisations listed "other" services that included music and dance lessons, drug abuse prevention, providing assistance to the South African Police Service (SAPS) and providing an advisory service for schools and government. 
GRAPH 2

EDUCATION SECTOR SERVICES

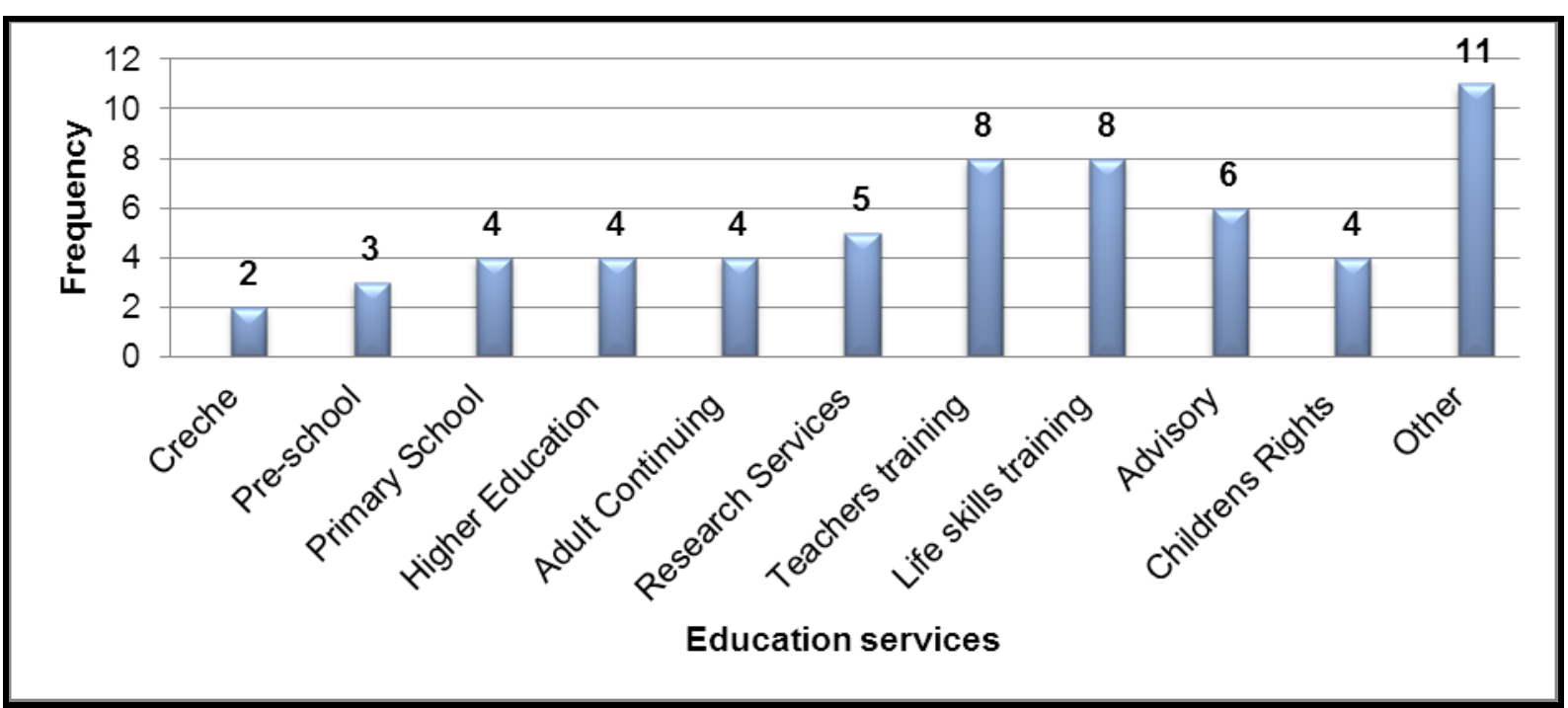

The National Health Act, 2003 (Act 61 of 2003) clearly distinguishes several types of services provided within the health sector and these were included in the questionnaire. Graph 3 reflects that of the 20 organisations operating in the health sector, 15 (75\%) provided services related to HIV/AIDS, while $8(40 \%)$ provided primary healthcare services.

GRAPH 3

\section{HEALTH SECTOR SERVICES}

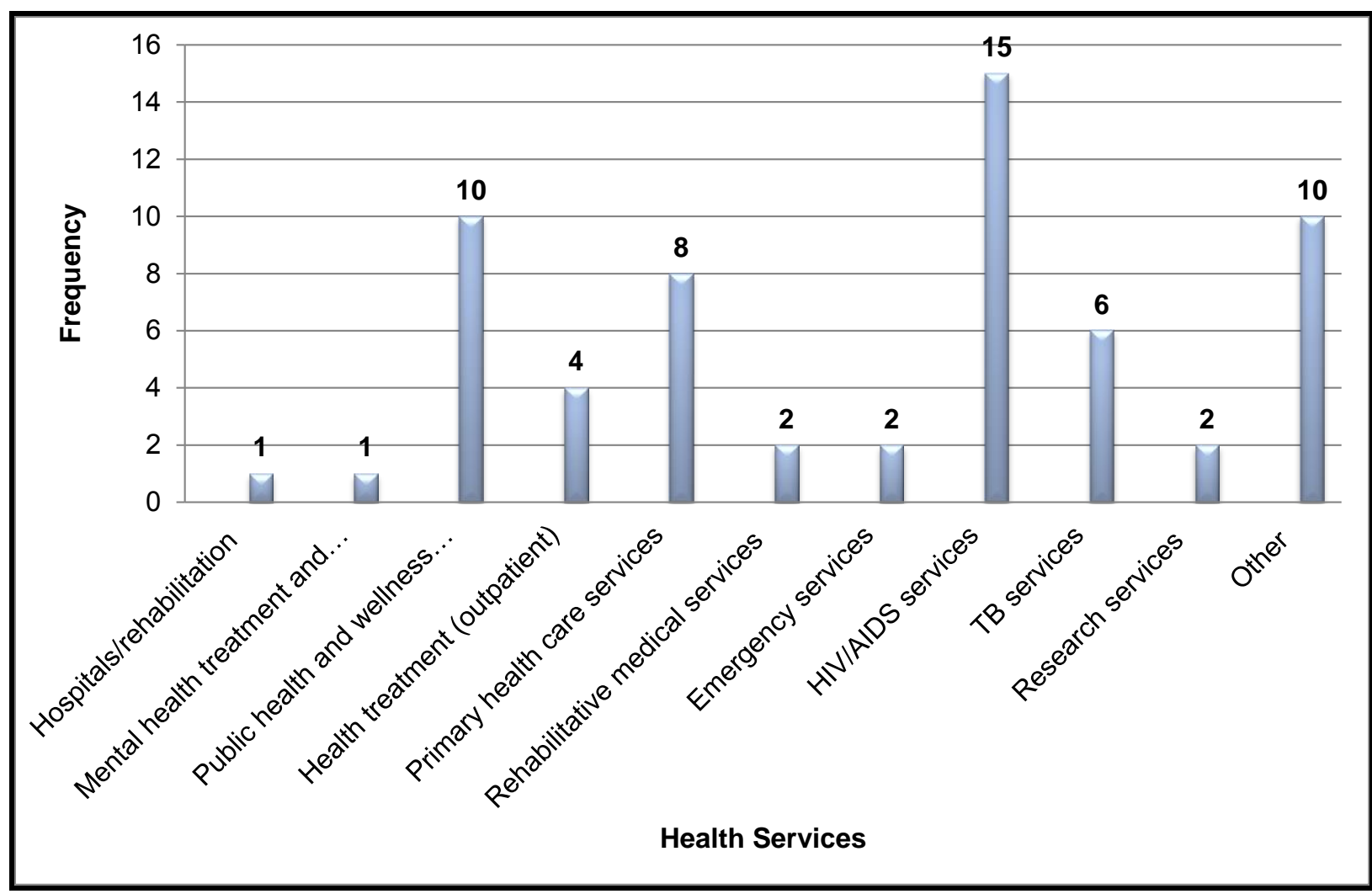




\section{SOURCES OF FUNDING}

The study sought to determine external and internal sources of NGO funding and the impact that the recession had on these funding sources. As reflected in Graph 4, 44 $(72 \%)$ respondent organisations received funds from individuals, while 41 (67\%) received funds from the corporate sector and $37(61 \%)$ from private foundations. Thirty (49\%) organisations identified the National Lottery and 29 (48\%) identified international donors as sources of funding.

Unlike the Kilbey study (2010:100), which reported significant levels of provincial government funding, only $26(43 \%)$ organisations indicated that they received funding from provincial government while $8(13 \%)$ identified the national government as a source of funding and $5(8 \%)$ indicated local government as a source of funding. While the National Development Agency (NDA) was established to primarily fund services in these three sectors, only one organisation reported the NDA as a source of funding. This low level of NDA funding is also reflected in a number of other studies - see, for instance, Smit (2005:356) and Kilbey (2010:100).

\section{GRAPH 4 \\ EXTERNAL SOURCES OF \\ FUNDING}

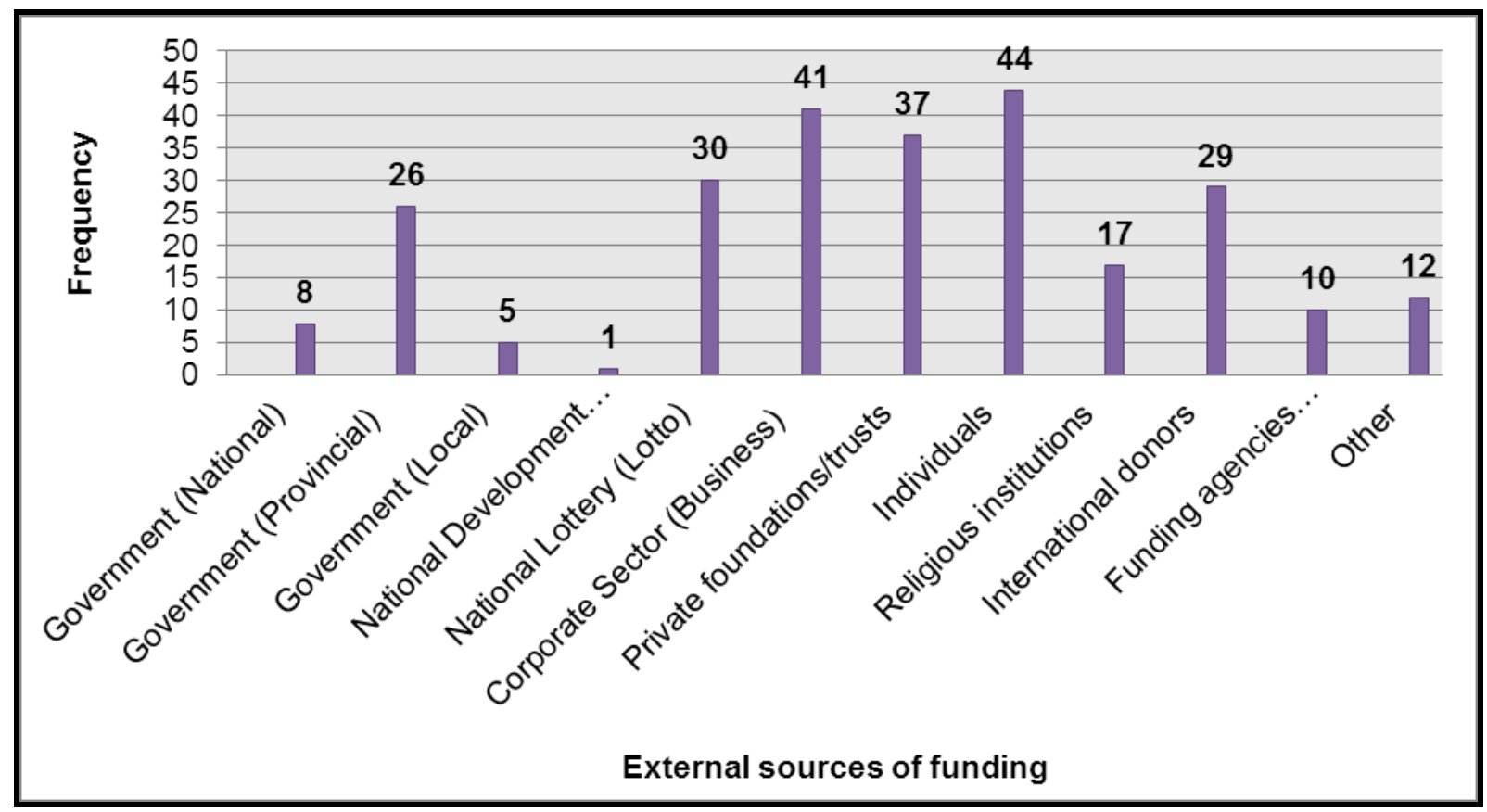

Apart from the external sources of funding, NGOs also generated income. Graph 5 reflects that a large majority (45 or 74\%) identified fundraising activities as a source of income. Nineteen organisations (31\%) charged service fees, while 14 (23\%) organisations indicated that they received funding from 'other' internal sources including from proposal writing, rental of office space, training fees, charity shops, accommodation and land rentals. A relatively low number (11 or 18\%) indicated trading (business) as an internal source of funding. 
GRAPH 5

INTERNAL SOURCES OF FUNDING

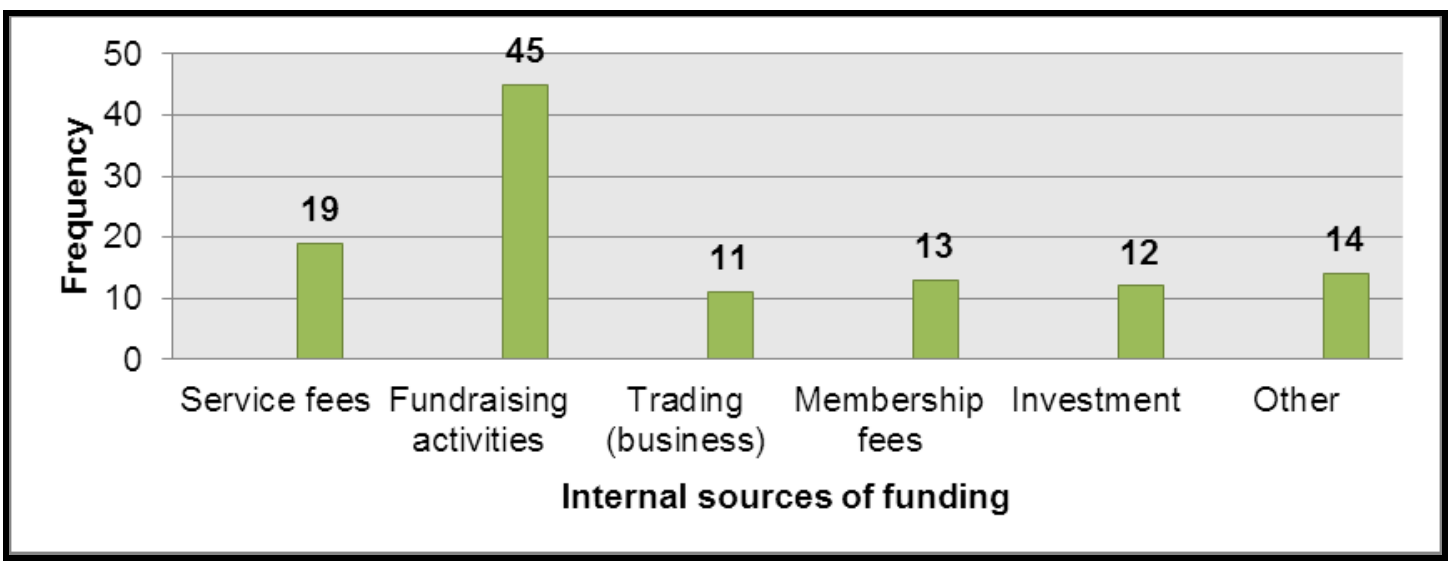

These results show that South African NGOs are on average actively engaged in raising their own funds. However, the fact that only a few chose trading as a source of funding indicates that South African NGOs are not strategic in adopting innovative business models to secure funding. There are studies which indicate that fundraising in South Africa is not optimally developed, mainly as a result of a number of issues. In the Kilbey study (2010:58), 57\% of the respondents indicated that insufficient fundraising staff was a major difficulty, while $28 \%$ perceived it as a moderate difficulty; Smit (2005:355) found that only $28 \%$ of respondent organisations had fundraising strategies.

\section{THE EFFECTS OF THE ECONOMIC RECESSION ON REVENUE}

The effect of the recession on revenue varied, with 31 organisations $(51 \%)$ having experienced an increase, $17(28 \%)$ a decrease and $11(18 \%)$ no change - see Graph 6. For those organisations which indicated their annual income had decreased, the average decrease amounted to $32 \%$, a rather substantial decrease in income. These findings contradict the findings of other studies, which reported a more substantial decrease in revenue. For example, Alliance for Nonprofit Excellence (2009:2) found that 73\% of respondents reported decreased revenues in their 2009 current fiscal year and $18 \%$ stated that at least $50 \%$ of their budget could be cut, while half the respondents reported at least a 20\% decrease. Furthermore, the Vancouver Foundation (2009:4) reported that 53\% of respondents experienced a drop in revenue in the 2009 fiscal year, with the average decline being 19 per cent. The Johns Hopkins Nonprofit Listening Project also reported a significant decrease $-51 \%$ of 363 non-profit organization surveyed nationally reported a decline in revenue (Salamon et al., 2009:1). 


\section{GRAPH 6 STATUS OF INCOME DURING ECONOMIC RECESSION}

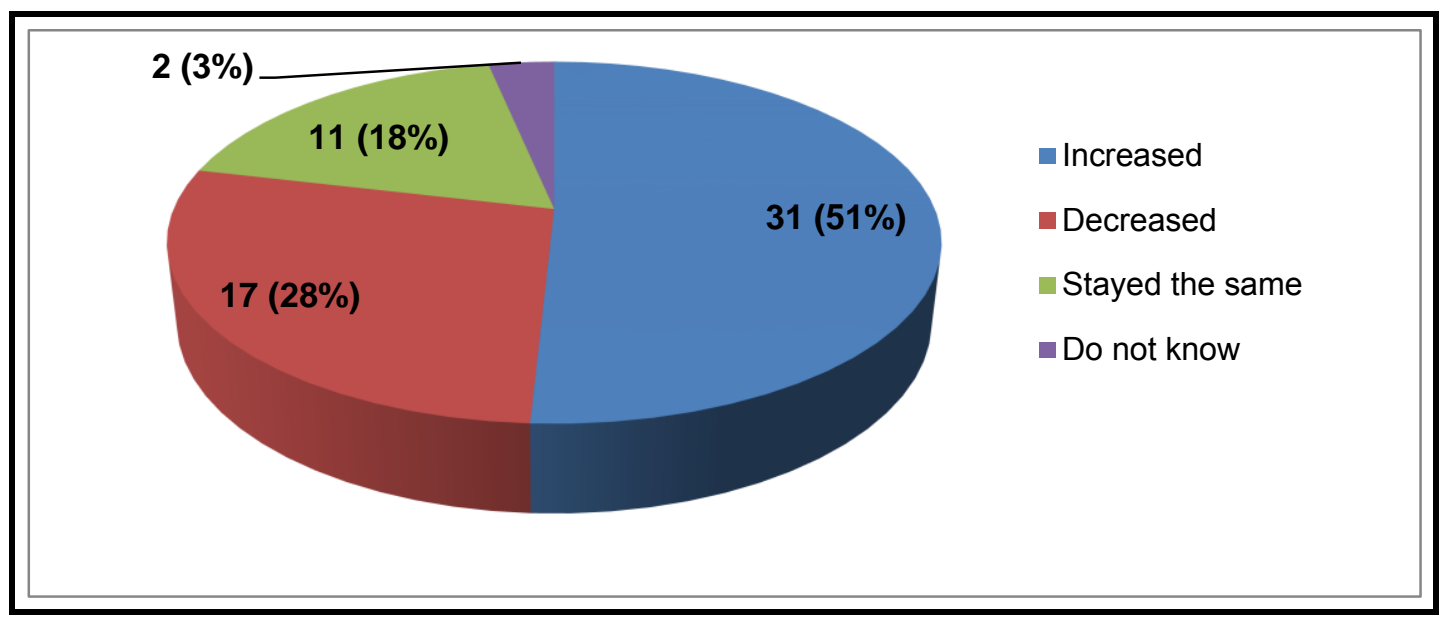

Respondent organisations were asked to indicate the status of their external and internal sources of funding during the economic recession. The options were to indicate whether the funds received from each source of funding was higher, the same, lower or unknown during the economic recession. Graph 7 reflects that $16(43 \%)$ organisations indicated lower, $16(43 \%)$ the same and $4(11 \%)$ higher funding from individuals. Furthermore, 15 $(40 \%)$ organisations stated that the funds received from the corporate sector were lower during the economic recession, while 13 (34\%) stated the funds had increased and 10 (26\%) reported that the funding amount remained the same. Fourteen organisations $(39 \%)$ stated that the funds received from private foundations were lower, $18(30 \%)$ the same and 4 (7\%) higher. These findings were in concert with the United Nations worldwide survey, which reported reductions from individual contributions, private foundations, international institutions and governments (Hanfstaengl, 2010). Of the 640 CSOs surveyed, 582 reported a decrease in the different categories of funding - of these, 147 said that there was a decline in direct personal contributions, 104 reported reductions by private foundations, 95 by international institutions, 87 by government and 71 by corporations (Hanfstaengl, 2010:24). The Alliance for Nonprofit Excellence study (2009) also found that organisations got less from almost all major categories of funding sources during the economic recession. 


\section{GRAPH 7 \\ STATUS OF FUNDING FROM DIFFERENT SOURCES DURING THE ECONOMIC RECESSION}

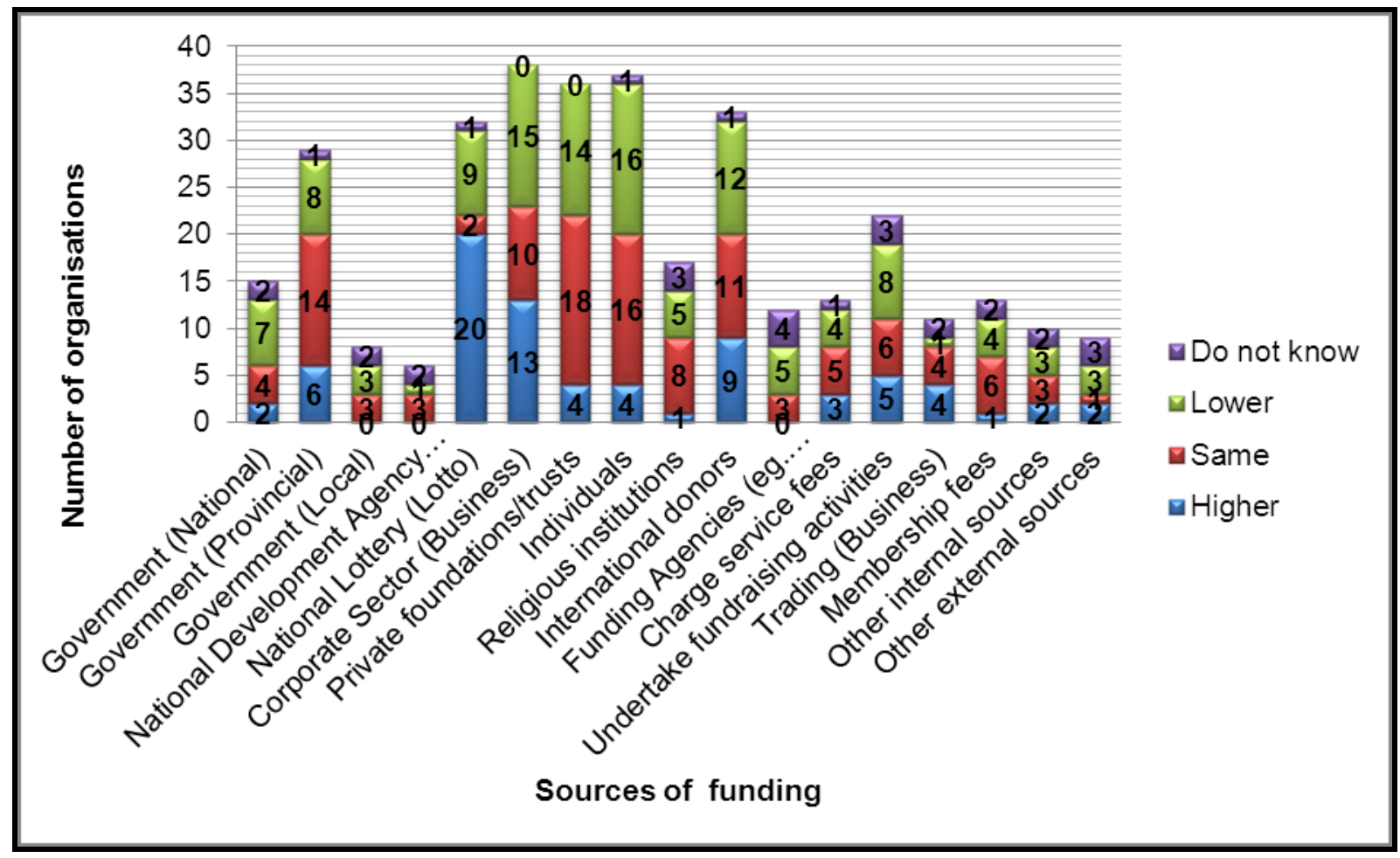

Of the 15 organisations that received funding from the national government, 7 (47\%) indicated that the funds they received were lower during the economic recession, while the levels of funding from provincial governments remained mostly the same during this period.

Significantly, Graph 7 reflects that $20(63 \%)$ of the 32 organisations that received National Lottery funding reported an increase in funding. However, not all NGOs received funding from the National Lottery and some reported a once-off grant during the economic recession.

Internal sources of funding did not change significantly during the recession, though 8 $(36 \%)$ organisations indicated that the funds received from fundraising activities during the economic recession was lower, while $5(23 \%)$ indicated that it was the same. Furthermore, $6(46 \%)$ organisations indicated that the funds received from membership fees were the same, while $4(31 \%)$ organisations indicated that they were lower.

Somewhat alarmingly, only 33 (54\%) organisations reported having cash reserves, while 28 (almost half $-46 \%$ ) had none. These results were very different to those of the Alliance for Nonprofit Excellence study (2009:7) which reported that $73 \%$ of respondent organisations had cash reserves, while only $27 \%$ did not.

Organisations were also asked to indicate how many months of operating expenditure they would be able to fund from their cash reserves. Table 1 reflects the number of 
months that cash reserves could cover operating costs of organisations, assuming that no additional funding was received.

\section{TABLE 1}

CASH RESERVES AND OPERATING COST OF RESPONDENT ORGANISATIONS

\begin{tabular}{|c|c|c|}
\hline Months & Number of organisations & $\%$ \\
\hline 0 & 37 & 61 \\
\hline $1-6$ & 11 & 18 \\
\hline $7-12$ & 10 & 16 \\
\hline $13-24$ & 2 & 3 \\
\hline 25 and more & 1 & 2 \\
\hline
\end{tabular}

A staggering $37(61 \%)$ of organisations would have had to close should there be a cessation of regular income as they did not have the reserves to cover future operations, while only $11(18 \%)$ organisations could survive for one to six months should regular income cease. These findings are similar to those of the Kilbey (2010) study which found that over half of the social service organisations surveyed would be unable to operate for more than three months from the date of their financial year end if they received no further funding within that timeframe. The results from the Alliance for Nonprofit Excellence research (2009:7) highlighted that 35\% of the respondent organisations had one to six months of reserves and $14 \%$ between six to seven months. Thirty per cent of those with reserves indicated they had started spending them to cover budget shortfalls (Alliance for Nonprofit Excellence research, 2009:7). It appears that NGOs are somewhat remiss when it comes to building sufficient reserves for a rainy day.

The study sought to compare total income and expenditure of organisations during the recession years to the non-recession years (2008, 2009 and 2010). Unfortunately, only $34(56 \%)$ organisations provided this information and as such not much credence can be attached to these figures. Social services organisations reflected accumulated deficits of R2 323327 in 2008, R6 656479 in 2009 and significantly, a huge surplus of R12 662 816 in 2010. Health sector organisations recorded accumulated surpluses throughout: R155 268 in 2008, R1 953177 in 2009 and R180 982 in 2010. Similarly, education sector organisations reflected surpluses throughout: R8 813241 in 2008, R10 124674 in 2009 and R15 849096 in 2010. Organisations operational in both the social service and health sectors reflected a cumulative deficit in 2008 of R2 444174 and cumulative surpluses of R4 105298 and R266 884 in 2009 and 2010, respectively. Organisations who operated in all sectors recorded surpluses throughout, namely R1 038730 in 2008, R1 368813 in 2009 and R286 767 in 2010.The total income and expenditure for all respondent organisations reflected a surplus throughout the period in question - R111 394764 in 2008, R144 827897 in 2009 and R203 983770 in 2010 as reflected in Graph 
8. While the social services sector suffered more than the other two sectors surveyed, cumulatively, income and expenditure increased throughout the three-year period surveyed - this despite the recession.

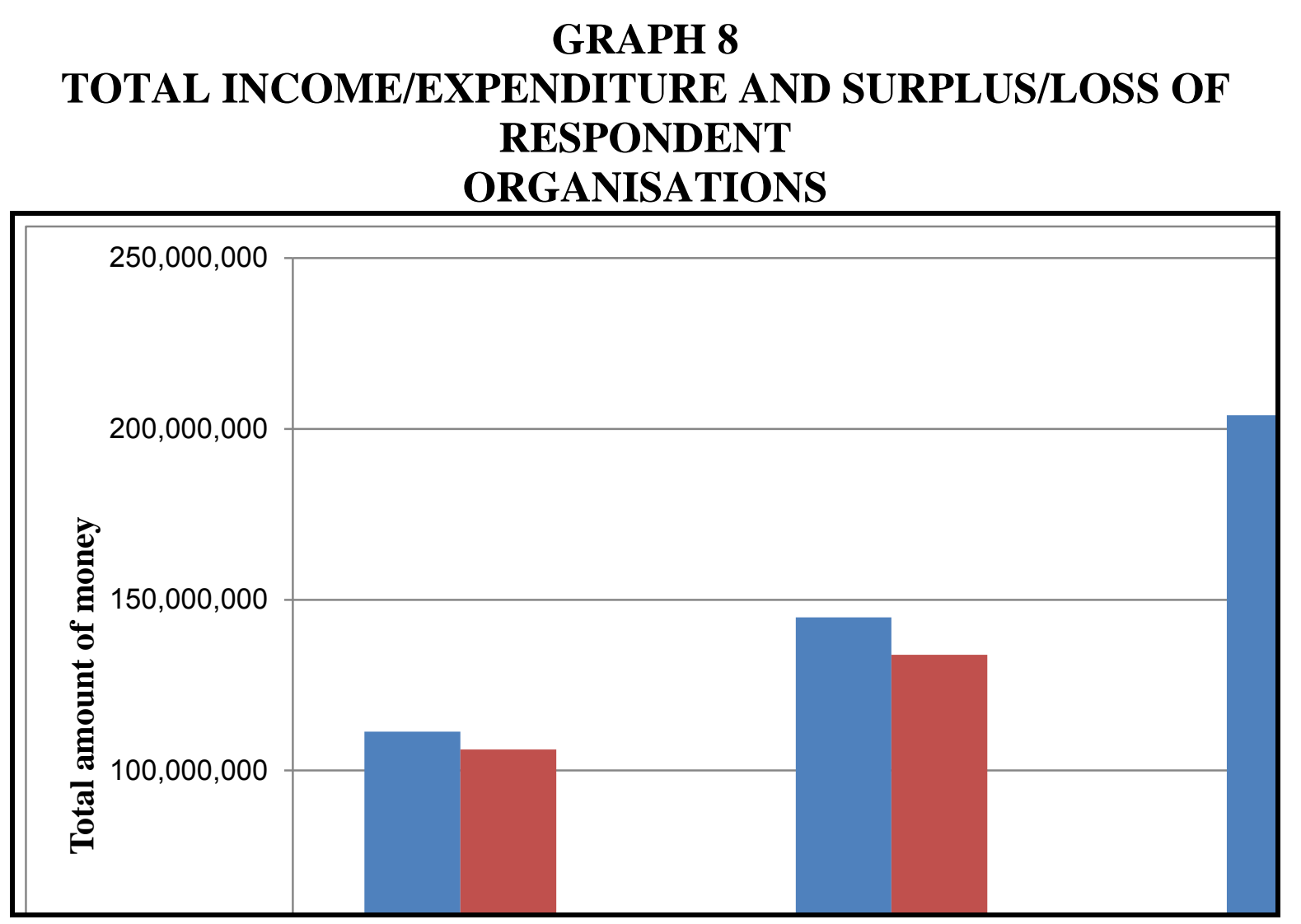

\section{SOME ORGANISATIONAL CONSEQUENCES OF DECREASED REVENUE}

As previously indicated (see Graph 6), 28 (46\%) organisations indicated that their annual income decreased. The consequences of this reported decrease are reflected in Graph 9. Fifteen organisations (88\%) indicated reduced reserve funds, 14 (82\%) organisations did not fill staff vacancies, while $12(71 \%)$ organisations reflected a deficit. Eight (47\%) organisations experienced increased service beneficiaries' waiting time, while $5(29 \%)$ organisations indicated a reduction in staffing. Other studies also indicated that the economic recession threatened cash reserves, which are a safeguard for organisations, especially during times of economic turmoil (Alliance for Nonprofit Excellence, 2009; Foster et al., 2009:7). The Alliance for Nonprofit Excellence study (2009:2) indicated that of the organisations that had cash reserves, $37 \%$ had funding for 1-6 months and 14\% for 6-12 months. Furthermore, 30\% of those with reserves said they had begun spending them to cover budget shortfalls as a result of the economic recession, while $49 \%$ indicated that they would end that fiscal year with a budget deficit (Alliance for Nonprofit Excellence study, 2009). Foster et al. (2009:7) also indicated that the economic recession forced NGOs to tap into their financial reserves. 


\section{GRAPH 9 \\ CONSEQUENCES OF DECREASED ANNUAL INCOME}

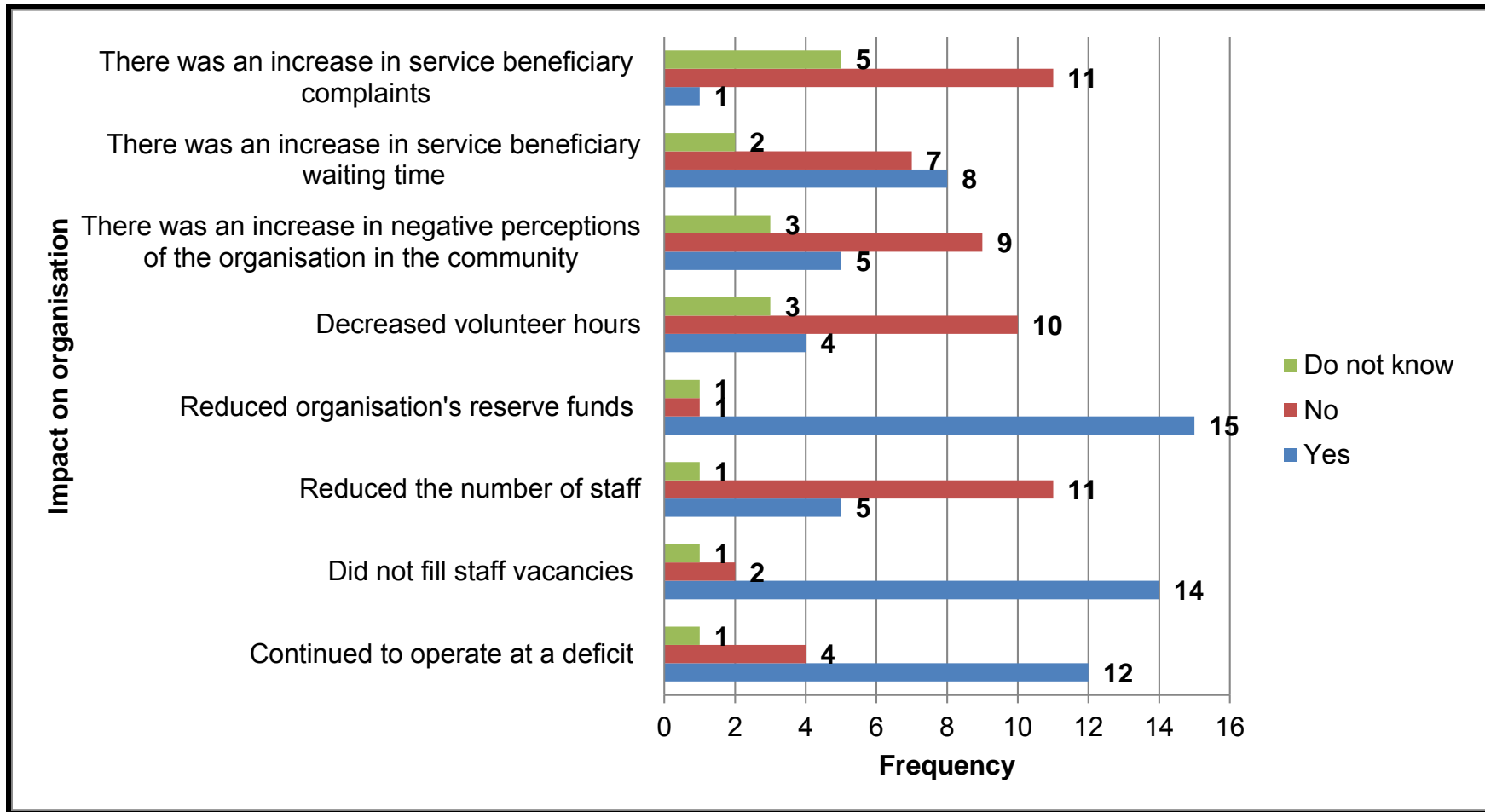

\section{STRATEGIES ADOPTED TO COUNTER THE IMPACT OF DECREASED REVENUE}

Many organisations were forced to adopt measures to counter the effects of the recession. As reflected in Graph 10,12 organisations (71\%) indicated that they reduced non-essential expenses, while $9(53 \%)$ organisations indicated that they improved their fundraising strategies. While $8(47 \%)$ organisations improved organisational efficiency, $7(41 \%)$ were forced to reduce services. These results are similar to those reported by CCVO (2009), Hanfstaengl (2010), Alliance for Nonprofit Excellence (2009) and SPNO (2009), which indicated that organisations implemented strategies to reduce their costs and/or to increase their income. For example, they implemented strategies that were staff-related such as reducing staff positions, reducing travelling expenses and networking with other organisations to provide services and/or strategies to increase funds for organisations. Even though the scope of this particular study did not allow for further exploration of the effectiveness of these strategies, it is clear that implementing such strategies was better than doing nothing. However, of concern was the reduction of services at a time when the need for such services had increased significantly, as will be reported later. 
GRAPH 10

\section{STRATEGIES IMPLEMENTED TO CURB THE IMPACT OF DECREASED REVENUE}

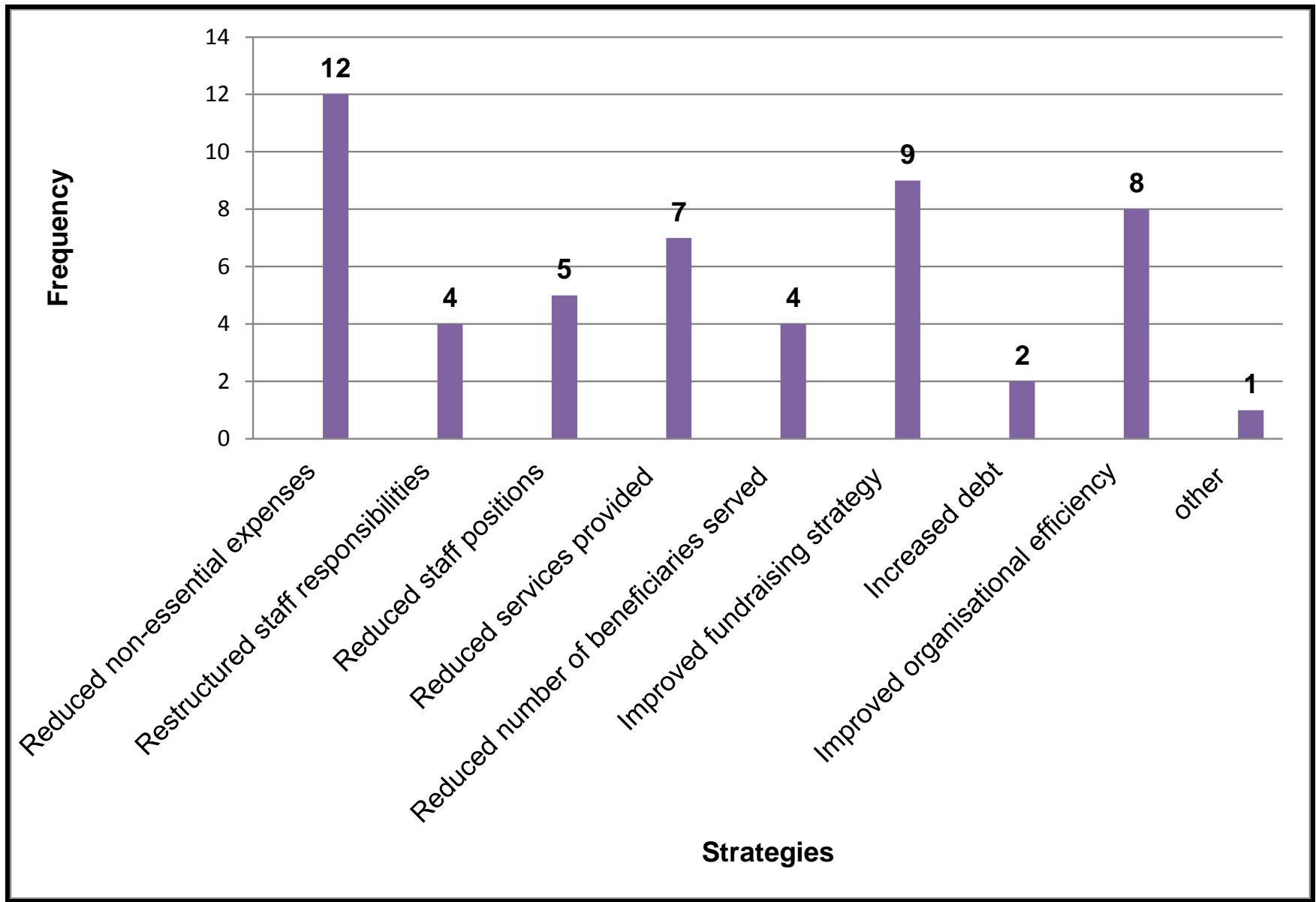

During the economic recession many organisations generally developed various strategies to increase revenue, some of which are reflected in Graph 11. While 52 (85\%) organisations improved their marketing efforts, 35 (57\%) organisations increased outreach to new service beneficiaries and, interestingly, 31 (51\%) organisations introduced fundraising activities via the internet.

NGOs exist to serve the less fortunate and disadvantaged in society. Sadly though, an economic recession is a double-edged sword; while it restricts access to resources, it increases the demands on services as the population faces increased unemployment and having less disposable income. 


\section{GRAPH 11}

STRATEGIES DEVELOPED TO INCREASE REVENUE

The recession forced the organisation to raise the price of goods or services provided by the organisation

Increased outreach to new service beneficiaries

The recession forced the organisation to reduce its office and other accommodation

Introduced fundraising activity via the internet

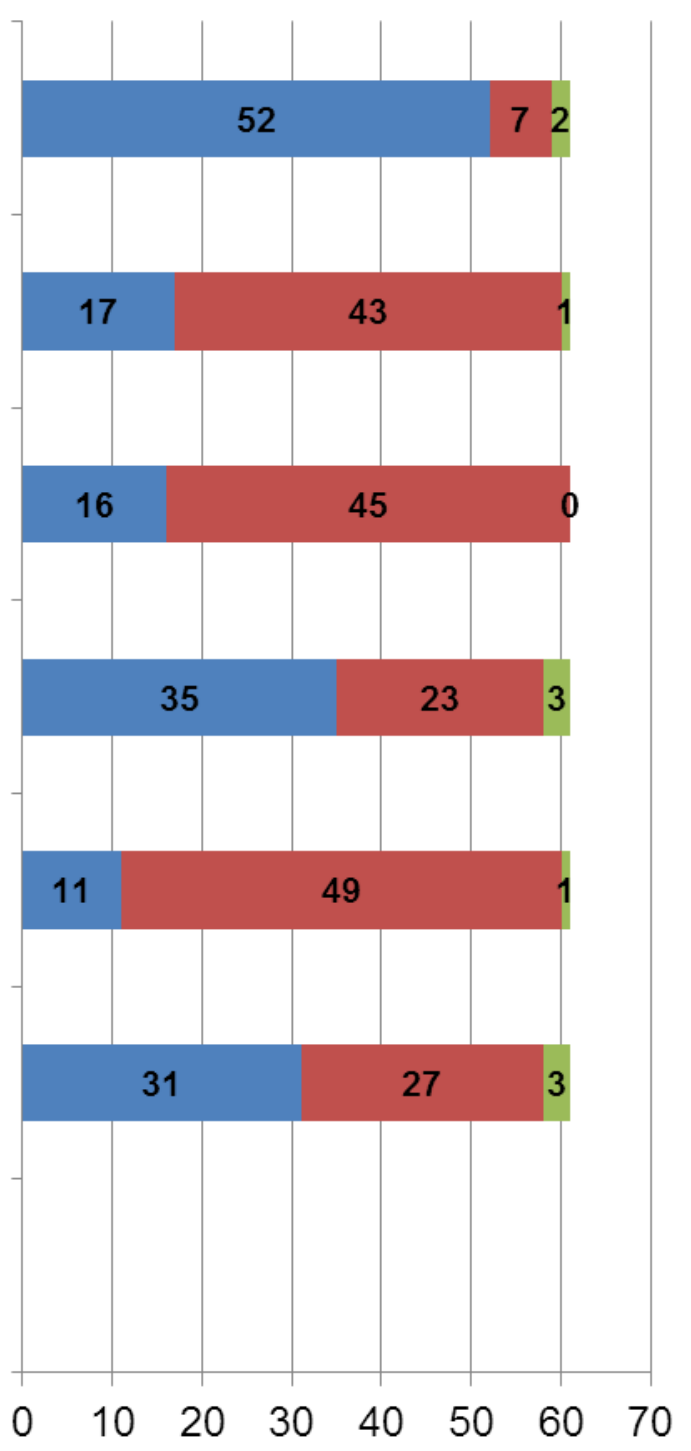

- Yes

No

Do not Know

Not surprisingly, an overwhelming $54(89 \%)$ organisations indicated that the demand for their organisation's programmes/services had increased during the economic recession, while only 8 per cent indicated that the demand for organisation's services remained the same - see Graph 12. This finding is similar to the results reported by the Alliance for Nonprofit Excellence (2009) and Hanfstaengl (2010) studies, which indicated that organisations experienced an increased demand for their services as a direct result of the economic recession. Similarly, SPNO (2009:2) reported that 60\% of the respondent organisations surveyed indicated an increase in service demand during the economic recession. The study by the Social Planning Council of Cambridge and North Dumfries (2009:3) reported that $68 \%$ of those surveyed indicated an increased demand for their services. Furthermore, the CCVO study (2009:3) highlighted that almost two thirds of the respondent organisations indicated an increased demand for their programmes and services. Naidoo and Nkuna (2009) also conveyed that there was an increased demand for the services of South African NGOs during the economic recession. 
GRAPH 12

DEMAND FOR ORGANISATIONS' PROGRAMMES/SERVICES

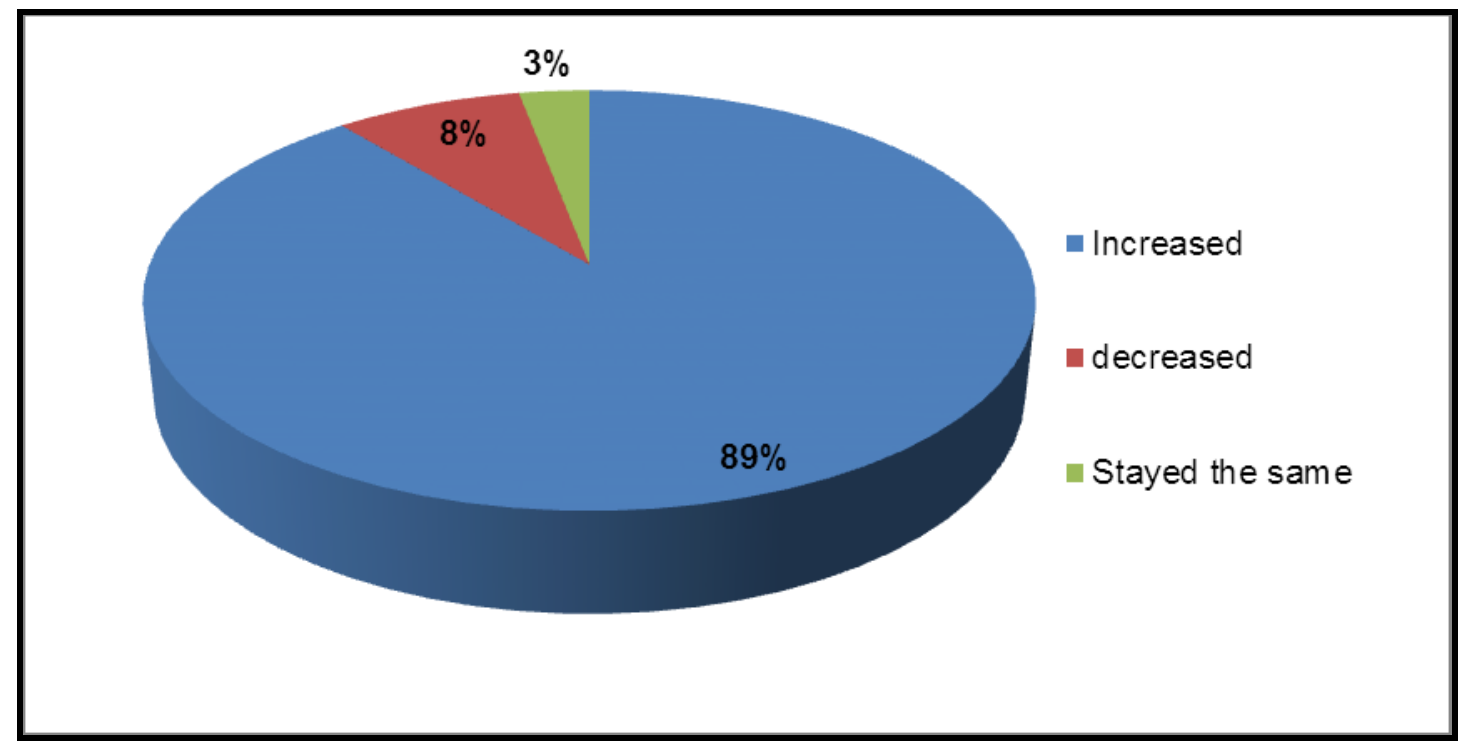

The increase in numbers of service beneficiaries rose substantially as a result of the economic recession - $47(77 \%)$ organisations indicated an increase in service beneficiary numbers, while only 8 (13\%) indicated a decreased - see Graph 13 .

\section{GRAPH 13}

\section{NUMBER OF SERVICE BENEFICIARIES DURING THE ECONOMIC RECESSION}

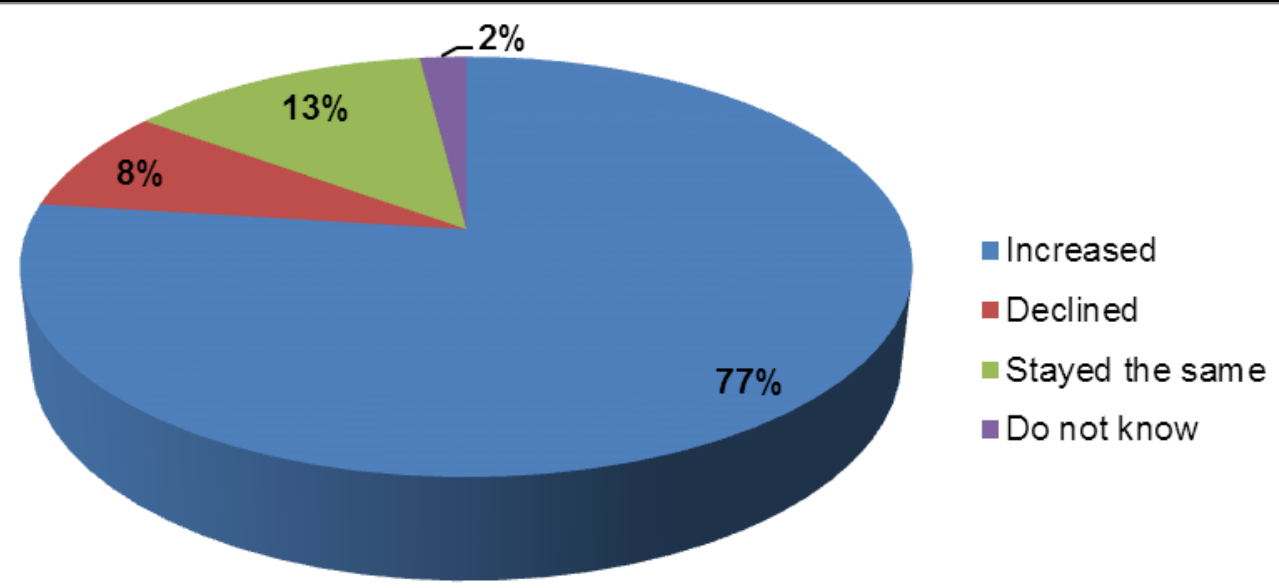

The SPNO study (2009:2) reported that 97\% of the respondent organisations indicated an increased number of people requesting services since 2008. Apart from the increase in service demand and beneficiary numbers, the profile of service beneficiaries changed during the recession period. As reflected in Graph 14, 23 (38\%) organisations indicated that the profile of their service beneficiaries had changed. This is similar to the findings reported by the Alliance for Nonprofit Excellence (2009) and the Hanfstaengl (2010) studies, which indicated organisations' client profiles included people who did not require their services prior to the recession. 
GRAPH 14

PROFILE CHANGE OF SERVICE BENEFICIARIES DURING THE ECONOMIC RECESSION

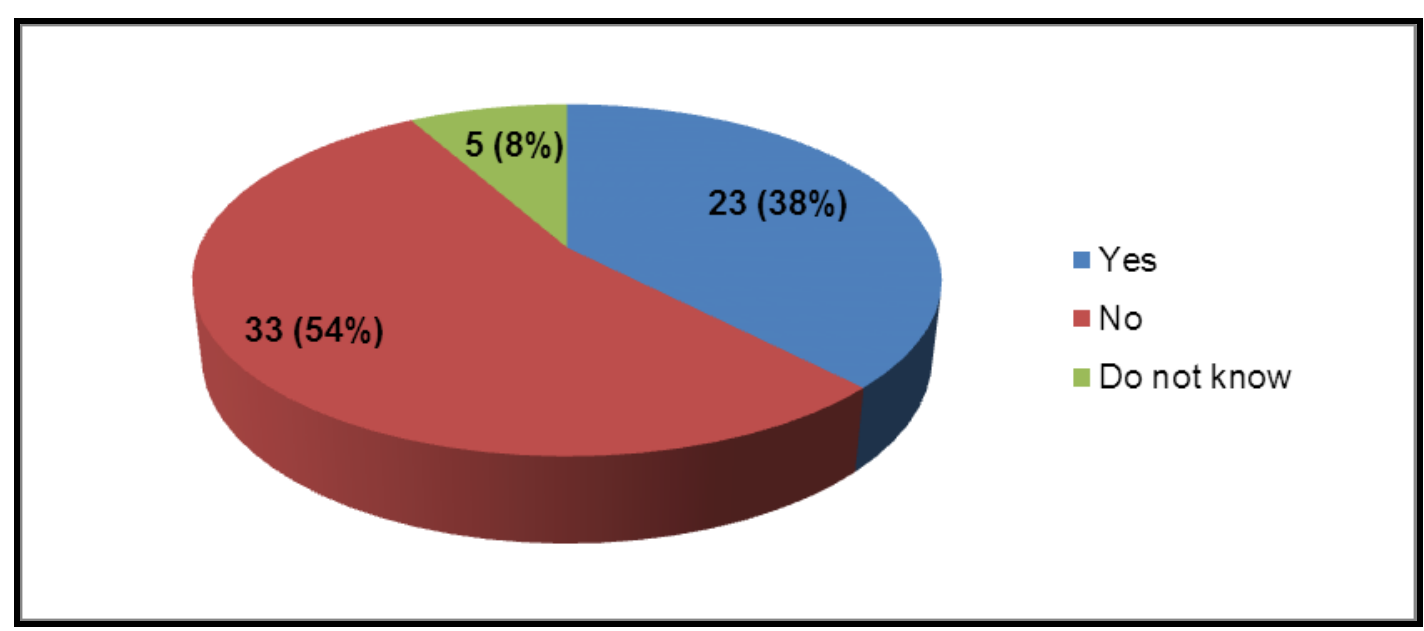

Interestingly, while $29(48 \%)$ organisations indicated that the nature of services demanded by service beneficiaries had not changed, a significant 27 (44\%) organisations indicated that the nature of services demanded had changed during the economic recession - see Graph 15.

GRAPH 15

\section{CHANGE IN NATURE OF SERVICES DEMANDED DURING THE ECONOMIC RECESSION}

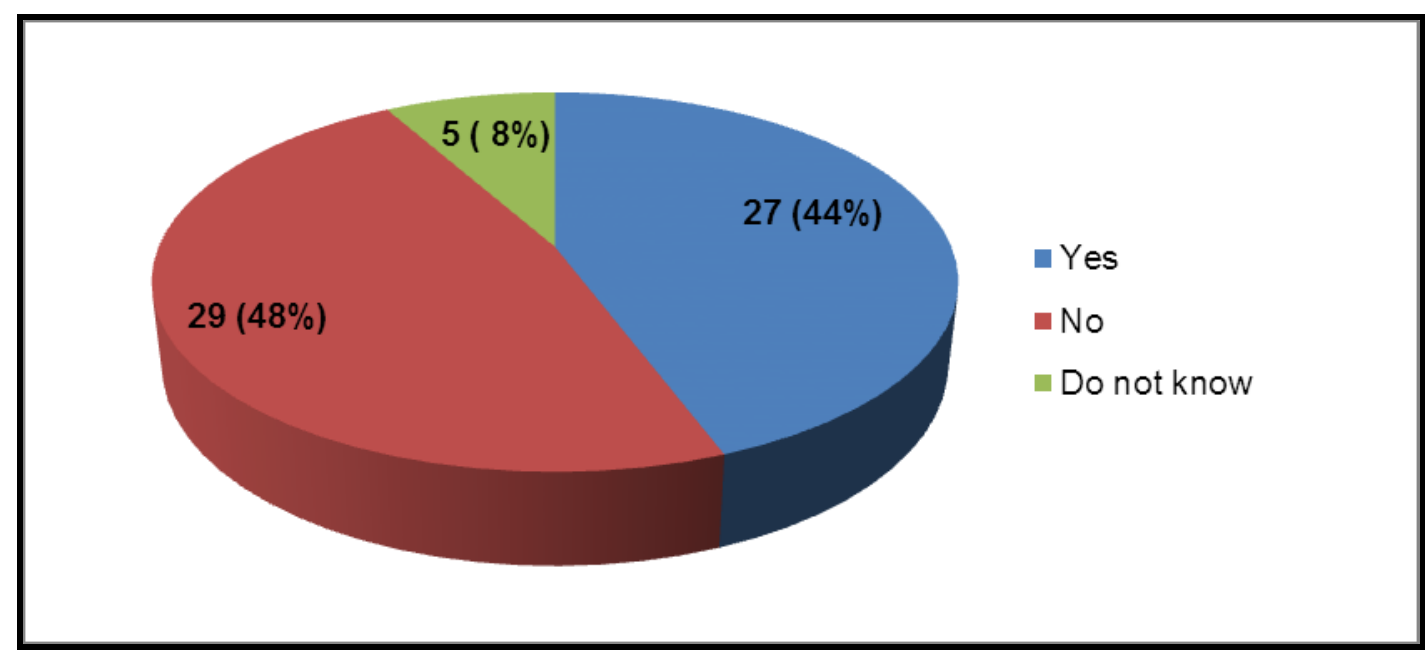

While this study did not specifically explore the nature of this change, other studies also reported an increased and urgent demand for services, notably that of employment services, job training programmes, bankruptcy and credit counselling, suicide counselling and crisis intervention programmes (Alliance for Nonprofit Excellence, 2009; Social Planning Network of Ontario 2009:2).

There were a number of organisational impacts recorded during the economic recession resulting from increased service demand. Understandably, 49 (91\%) organisations demanded more support from donors, as reflected in Graph 16. Forty-two (78\%) organisations indicated that there was an increased demand on organisational resources 
to cover the cost of increased service demand, while 40 (74\%) organisations indicated that there had been an increased demand on movable assets. Significantly, 29 organisations indicated an increase in staff exhaustion and just under a half reported an increased reliance on volunteers and students. The Social Planning Council of Cambridge and North Dumfries study (2009) reported increased caseloads, more hours worked without additional staff, increased human resources costs, increased stress on staff and the organisation, and an inability to provide clients with the holistic support they needed.

\section{GRAPH 16 \\ THE IMPACT OF INCREASED SERVICE DEMAND ON ORGANISATION}

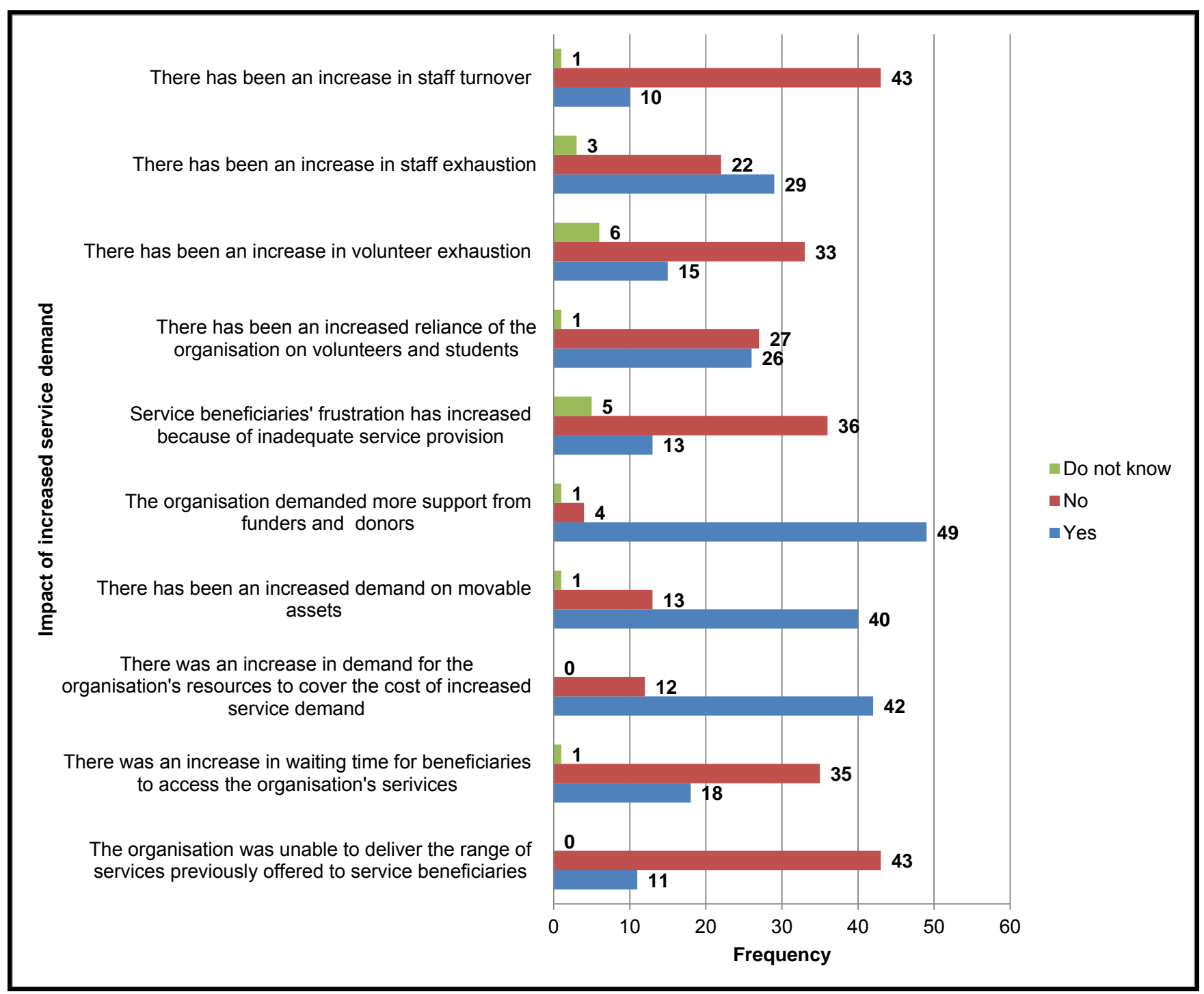

There were quite a number of strategies that organisations employed to curb the impact of increased service demand on organisations - see Graph 17. Laudably, 43 (78\%) organisations provided more services within their existing envelope of resources. Twenty-four (44\%) organisations indicated that they collaborated with other similar 
organisations to deliver services, while $18(33 \%)$ organisations indicated that they reallocated programme resources. It is surprising that $43(78 \%)$ organisations did not do anything to effectively address the increased service need. These findings are similar to those reported by the SPNO (2009:23) and Social Planning Council of Cambridge and North Dumfries (2009:3) studies, which found that service output was increased without staff expansion (69\%) but rather by increasing volunteer hours (46\%) and expanding the programme staff time and service hours $(28 \%)$.

\section{GRAPH 17 \\ STRATEGIES IMPLEMENTED TO RESPOND TO INCREASED SERVICE DEMAND}

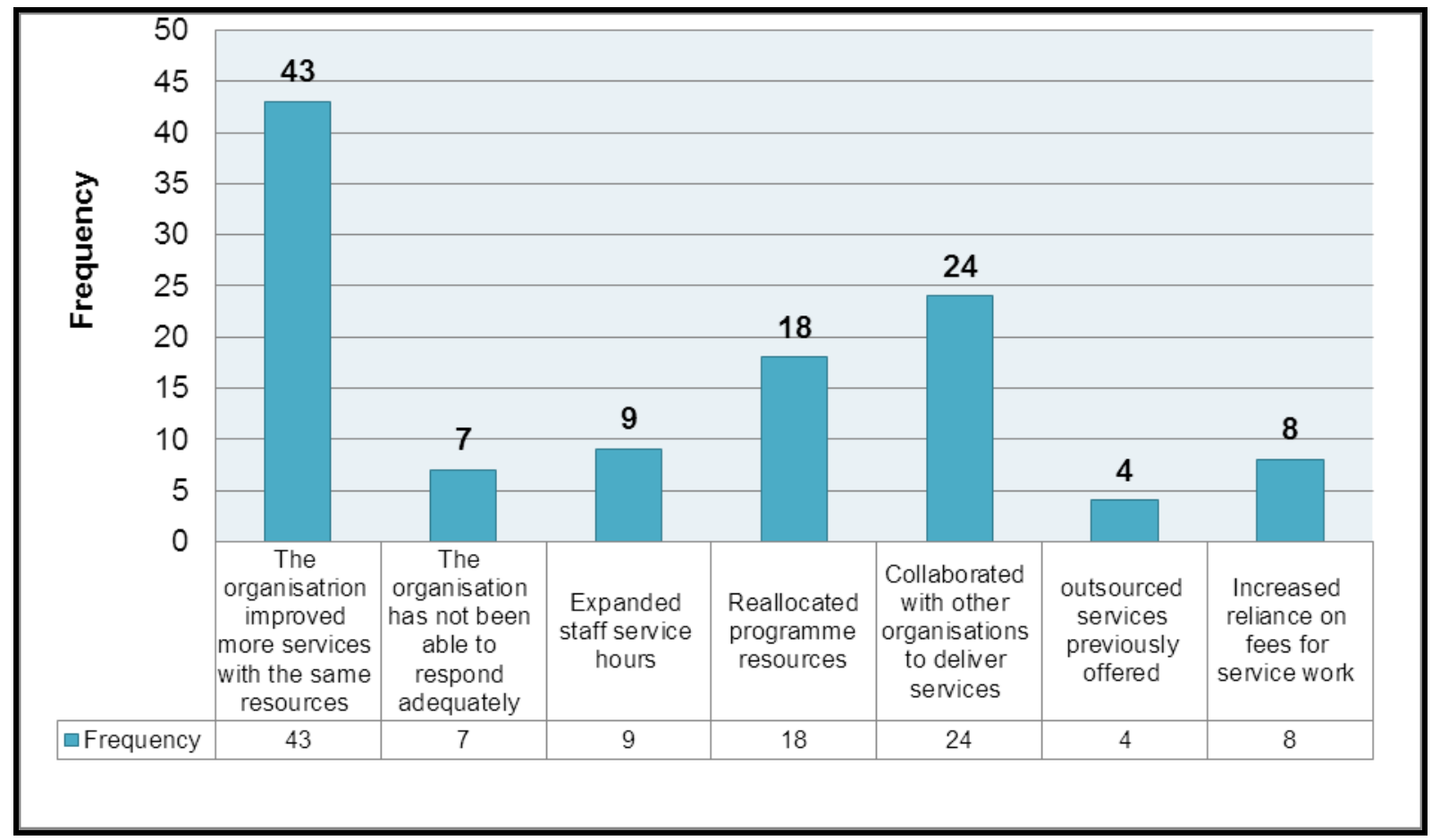

Apart from some organisations expanding staff service hours, the impact of the recession on staffing remained somewhat limited, with the large number of negative responses reflected in Graph 18. That said, 31 (51\%) organisations indicated that they had to redefine job descriptions, $28(46 \%)$ had to reduce bonuses, $28(46 \%)$ did not fill vacancies, 24 (39\%) had to reduce travelling expenses for staff, 21 (34\%) had to reduce staff training/professional development, 19 (31\%) froze salary increases and $16(26 \%)$ could not promote staff. 
GRAPH 18

THE IMPACT OF THE ECONOMIC RECESSION ON THE ORGANISATIONS' PERSONNEL

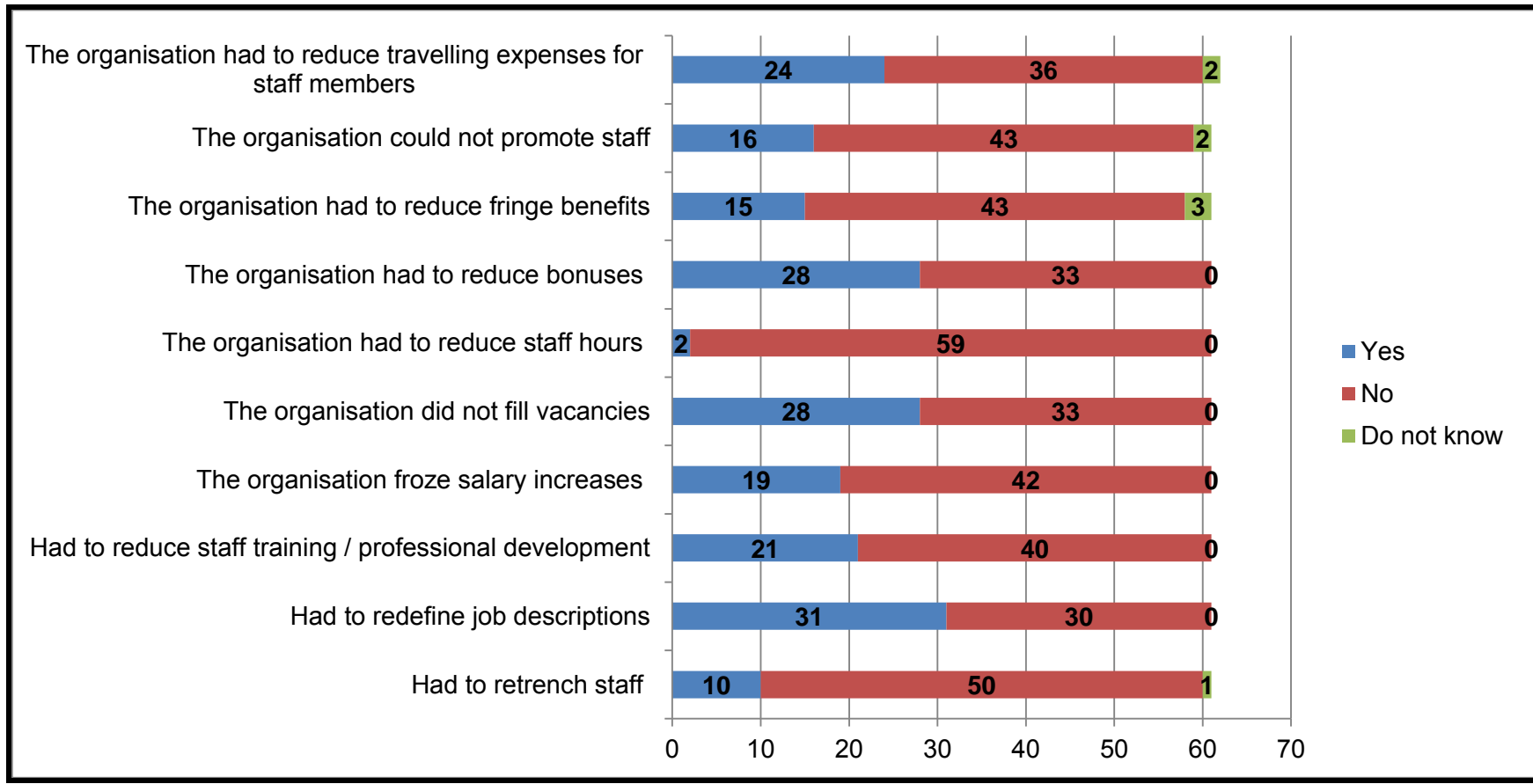

While the findings thus far presented have concentrated on the negative effects of the economic recession and how organisations responded to it, there are also positive outcomes of the economic recession that warrant mention. According to Graph 19, 57 (93\%) organisations indicated that the economic recession created an opportunity for greater awareness of using resources more efficiently. Furthermore, 52 (85\%) organisations indicated that the economic recession led to greater visibility of the organisation within the community. Forty-eight (79\%) respondent organisations indicated that the economic recession led to their programmes becoming more focused. The same number of organisations indicated that there was greater availability of organisations for collaboration and partnership. Forty-seven (77\%) organisations indicated that the economic recession promoted greater financial transparency within the organisation. These results are similar to the research results from the CCVO (2009) study, which highlighted that organisations could learn some positive lessons from the economic recession, such as more efficient use of resources. Furthermore, this study argued that the financial crisis could also lead to increased financial accountability and transparency, both from the donors and NGOs. The results of such studies also highlighted that during an economic recession, there are more organisations available for collaboration and partnership. 


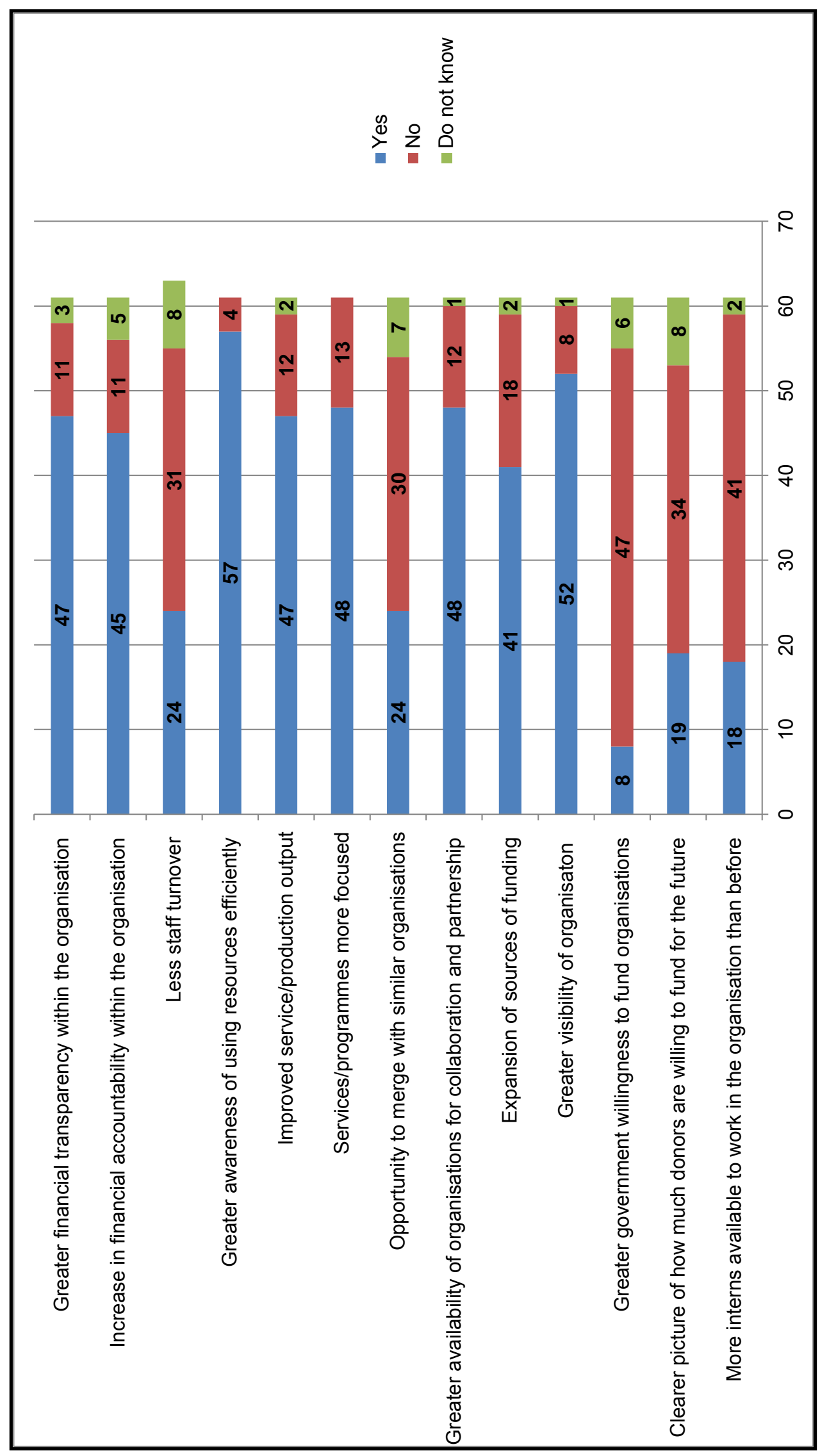

Social Work/Maatskaplike Werk 2013:49(1) 


\section{CONCLUSION}

During recessions, income from external sources is invariably more limited, while the need for services is usually significantly higher, placing organisations in a very vulnerable situation. South African NGOs suffered a fate no different, albeit less severe, from that of their international counterparts. The South African NGO sector's substantial reliance on external sources of funding and the rather limited capacity to generate funding from various sources makes it more vulnerable to recessions. Many organisations reported that government did not provide sufficient funding during the recession, nor did they step in to replace other sources of income that were reduced during the recession. Given the increase in services need during a recession and the large number of indigent who are cared for by the NGO sector, it would behove the government to increase its contribution to this sector. However, this sector must also increase efforts to become more economically independent and formulate contingency plans to deal with financial insecurity - importantly, financial reserves should be sufficient to counter any threat to regular income. The sector must also guard against decreasing service quantity or quality during a recessionary period. The long-term cost of not providing services when most needed can be significant.

Even though the economic recession was associated with negative consequences for many NGOs, it also presented a parcel of opportunities, of which many NGOs took advantage - many are now more efficient and better prepared for a similar crisis.

\section{REFERENCES}

AJAM, K. 2009. NGOs feel the pinch of recession. IOL news, 23 March, 2009. [Online] Available: http://www.iol.co.za/news/south-africa/ngos-feel-the-pinch-of-recession-1.437963\#more [Accessed: 01/04/2010].

ALLIANCE FOR NONPROFIT EXCELLENCE. 2009. Downstream and in demand: Mid-South nonprofits and the economic crisis. [Online] Available: http://www. npexcellence.org/documents/DownstreamReportFINAL.pdf [Accessed: 01/04/2010].

BUSTILLO, I. \& VELLOSO, H. 2009. The global financial crisis: what happened and what next? ECLAC- Studies and Perspectives Series Washington, No. 4. [Online] Available: http://www.ilo.org/public/libdoc/igo/2009/431716.pdf [Accessed: 20/06/2011].

CALGARY CHAMBER OF VOLUNTARY ORGANISATIONS (CCVO). 2009. Stretched to the limit: Economic Impact Survey. Alberta's Non-profits and charities. Calgary Chamber of Voluntary Organisations. Calgary. [Online] Available: http://www.calgarycvo.org/sites/default/files/resources/Economic_Impact_Survey_Rele ase_Nov_2009_0.pdf. [Accessed: 20/06/2011].

FIELDING, N., LEE, R.M. \& BLANK, G. (eds) 2008. The SAGE Handbook of online research methods. Thousand Oaks: SAGE Publications Ltd.

FOSTER, W., PERREAULT, G. \& SABLE, S. 2009. Managing in tough times: May 2009 non profit leaders survey update. The Bridgespan Group. Inc. [Online] 
Available: $\quad$ http://www.bridgespan.org/nonprofit-managing-in-tough-times-surveyupdate-may-2009.aspx [Accessed: 20/06/2011].

HANFSTAENGL, H.E.M. 2010. Impact of the global economic crisis on civil society organisations. [Online] Available: http://ngosocdev.files.wordpress.com/ 2010/01/fullstudy-on-impact-of-global-crises-on-csos-2-25-10.pdf [Accessed: 20/06/2011].

KALIS, A. 2000. Government - NGO Partnerships for Social Service Delivery. Poverty, Social Welfare and Social Development Challenges for 21st Century: 29th ICSW International conference on Social Welfare. Cape Town, 23-27 October 2000. [Online] Available: http://www.icsw.org/global-conferences/gov-ngo-partnership.htm [Accessed: 15/06/2011].

KANITHI, N. 2010. A comparative global study of the impact that information and web technologies have on the sustainability and growth potential of non-profit organizations in developed and developing countries. Cape Town. University of Cape Town. (MA thesis)

KILBEY, B. 2010. The state of fundraising within the non-profit social service sector: a study to determine how and to what level of success South African NPOs are managing and operating their fundraising functions. Cape Town. University of Cape Town. (MA thesis)

NAIDOO, Y. \& NKUNA, B. 2009. NGOs face cash crunch due to financial crisis. West Cape News, 6 March 2009. [Online] Available: http://westcapenews.com/?p=468 [Accessed: 10/12/2010].

PETER, M. 2008. Charities, NGOs funds 'drying up'. IOL News November 92008. [Online] Available: http://www.iol.co.za/news/politics/charities-ngos-funds-dryingup-1.423572 [Accessed: 28/02/2011].

PHILIP, R. 2009. Charities going burst as recession hits: warning that cash crisis will have 'catastrophic impact'. Sunday Times. [Online] Available: http://www.timeslive.co.za/sundaytimes/article82559.ece [Accessed: 20/02/2011].

RAPOO, T. 2010. Funding Crisis for Research NGOs in South Africa Looming Larger Than Ever. SANGONeT, NGO News and Views Friday, July 23, 2010. [Online] Available: http://www.sangonet.org.za/article/funding-crisis-research-ngos-south-africalooming-larger-ever [Accessed: 23/02/2011].

REPUBLIC OF SOUTH AFRICA. 1978. Fundraising Act, 1978 (Act 107 of 1978). Government Gazette, 156, No. 6099 (30 June). Pretoria: Government Printer.

REPUBLIC OF SOUTH AFRICA. 1989. Disclosure of Foreign Funding Act, 1989 (Act 26 of 1989). Government Gazette, 285, No.11779 (23 March). Pretoria: Government Printer.

REPUBLIC OF SOUTH AFRICA. 2003. National Health Act (Act 61 of 2003). Government Gazette, 469, No. 869 (23 July). Pretoria: Government Printer.

SALAMON, L.M., GELLER, S.L. \& SPENCE, K.L. 2009. Impact of the 2007-09 Economic Recession on Nonprofit Organizations. Listening Post Communiqué No. 14. 
Johns Hopkins Institute for Policy Studies, Baltimore, MD. [Online] Available: http://ccss.jhu.edu/wp-content/uploads/downloads/2011/09/LP_Communique14_2009 .pdf [Accessed: 20/02/2013].

SALGADO, I. 2010. Recession may alter priorities but real philanthropists still give freely. Business Report (National). Thursday 8 April: 7.

SANDRA, A. 2008. The Great Recession 2008-2009. (What are we going to do about it?). [Online] Available: http://www.aflcio-hit.com/userassets/Documents/Economic analysis/2008_great_recession.pdf [Accessed: 20/06/2011].

SMIT, A. 2005. Funding strategies: surviving imperial intentions, protean policies and ruthless reality. Social Work/Maatskaplike Werk, 41(4):349-360.

SOCIAL PLANNING NETWORK OF ONTARIO (SPNO). 2009. Hard hit: impact of the economic downturn on non-profit Community Social Service in Ontario. [Online] Available: http://socialplanningtoronto.org/wpcontent/uploads/2009/ 10/HARD HIT Impact of the Economic Recession on Nonprofit Community Soci al_Services_in_Ontario.pdf [Accessed: 20/06/2011].

SOCIAL PLANNING COUNCIL OF CAMBRIDGE AND NORTH DUMFRIES. 2009. Responding to the economic downturn: Nonprofits in Cambridge and North Dumfries. [Online] Available: http://nonprofitsectormanitoba.ca/resources/masterresource-file/ Financial\%20Strains.pdf [Accessed: 22/06/2011].

SOUTH AFRICAN NGO NETWORK (SANGONet). 2011. Prodder Directory Online. Available: http://www.prodder.org.za/about-prodder [Accessed 10/06/2011].

SOUTH AFRICAN HISTORY ONLINE (SAHO). 1989. The many faces of Apartheid repression. History Matters Blog. [Online] Available: http://www.sahistory.org.za /article/many-faces-apartheid-repression [Accessed: 17/07/2011].

SWILLING, M. \& RUSSELL, B. 2002. The size and scope of the non profit sector in South Africa. Johannesburg and Durban: Graduate School of Public and Development Management, University of the Witwatersrand and the Centre for Civil Society, University of Natal.

THAW, R. 2009. NGOs Struggle to find Funding due to credit Crunch. EWN. [Online] Available: http://www.ewn.co.za/articleprog.aspx?id=7879 [Accessed: 22/06/2011].

VANCOUVER FOUNDATION. 2009. Weathering the storm: a survey of non-profit organisations and charities in British Columbia. [Online] Available: http://www.cccabc.bc.ca/res/pubs/pdf/VanFdn_WeatheringTheStorm.pdf [Accessed: 22/06/2011].

Ms Eyesus Gebreselassie-Hagos, Recent Masters graduate in Social Science (Social Policy and Management), University of Cape Town; Prof André de V Smit, Department of Social Development, University of Cape Town, Cape Town, South Africa. 